\title{
Blastocyst transfer in mice alters the placental transcriptome and growth
}

\author{
Katerina Menelaou¹,2, Malwina Prater ${ }^{2}$, Simon J Tunster ${ }^{1,2}$, Georgina E T Blake ${ }^{1,2}$, \\ Colleen Geary Joo ${ }^{3}$, James C Cross ${ }^{4}$, Russell S Hamilton ${ }^{2,5}$ and Erica D Watson ${ }^{1,2}$ \\ ${ }^{1}$ Department of Physiology, Development, and Neuroscience, University of Cambridge, Cambridge, UK, ${ }^{2}$ Centre for \\ Trophoblast Research, University of Cambridge, Cambridge, UK, ${ }^{3}$ Transgenic Services, Clara Christie Centre for \\ Mouse Genomics, University of Calgary, Calgary, Alberta, Canada, ${ }^{4}$ Department of Comparative Biology and \\ Experimental Medicine, University of Calgary, Calgary, Alberta, Canada and ${ }^{5}$ Department of Genetics, University of \\ Cambridge, Cambridge, UK
}

Correspondence should be addressed to E D Watson; Email: edw23@cam.ac.uk

\begin{abstract}
Assisted reproduction technologies (ARTs) are becoming increasingly common. Therefore, how these procedures influence gene regulation and foeto-placental development are important to explore. Here, we assess the effects of blastocyst transfer on mouse placental growth and transcriptome. $\mathrm{C} 57 \mathrm{Bl} / 6$ blastocysts were transferred into uteri of B6D2F1 pseudopregnant females and dissected at embryonic day $\mathbf{1 0 . 5}$ for analysis. Compared to non-transferred controls, placentas from transferred conceptuses weighed less even though the embryos were larger on average. This suggested a compensatory increase in placental efficiency. RNA sequencing of whole male placentas revealed 543 differentially expressed genes (DEGs) after blastocyst transfer: 188 and 355 genes were downregulated and upregulated, respectively. DEGs were independently validated in male and female placentas. Bioinformatic analyses revealed that DEGs represented expression in all major placental cell types and included genes that are critical for placenta development and/or function. Furthermore, the direction of transcriptional change in response to blastocyst transfer implied an adaptive response to improve placental function to maintain foetal growth. Our analysis revealed that $\mathrm{CpG}$ methylation at regulatory regions of two DEGs was unchanged in female transferred placentas and that DEGs had fewer gene-associated CpG islands (within $\sim 20 \mathrm{~kb}$ region) compared to the larger genome. These data suggested that altered methylation at proximal promoter regions might not lead to transcriptional disruption in transferred placentas. Genomic clustering of some DEGs warrants further investigation of long-range, cis-acting epigenetic mechanisms including histone modifications together with DNA methylation. We conclude that embryo transfer, a protocol required for ART, significantly impacts the placental transcriptome and growth.

Reproduction (2020) 159 115-132
\end{abstract}

\section{Introduction}

More than seven million babies worldwide have been born using some form of assisted reproduction technology (ART) largely as a treatment approach to infertility (European Society of Human Reproduction and Embryology (ESHRE) 2018 February 18. ART Fact Sheet. Retrieved from https://www.eshre.eu/. Grimbergen, Belgium). ART includes a range of procedures with varying degrees of invasiveness (e.g., superovulation, in vitro fertilisation (IVF), intracytoplasmic sperm injection, embryo culture, embryo biopsy, gamete and embryo vitrification, and blastocyst transfer). While ART is generally safe, growing evidence suggests that individuals born using these technologies are at an increased risk of intrauterine growth restriction, perinatal complications (Quinn \& Fujimoto 2016), and/ or developing cardiovascular disease later in life (Tararbit et al. 2013, Valenzuela-Alcaraz et al. 2013, Liu et al. 2015, Guo et al. 2017). Since optimal placental function is required for normal foetal growth and development, it is predicted that placenta pathologies are responsible for some of the adverse pregnancy outcomes associated with ART (Delle Piane et al. 2010, Thomopoulos et al. 2013, Choux et al. 2015). Indeed, ART pregnancies were overrepresented in the highest quartile of placental weight and underrepresented in the highest quartile of birthweight (Haavaldsen et al. 2012).

To explore the effects of ART on placental structure and function, animal models have been utilised. Similar to humans, the mouse placentation site is composed of three major layers: the outer maternal layer, which includes decidual cells of the uterus, maternal immune cells, and the maternal vasculature that brings blood to and from the implantation site; the metabolic 'junctional' region, containing many 
endocrine cells and which attaches the placenta to the uterus through the invasion of trophoblast cells; and an inner layer composed of highly branched villi required for nutrient, gas, and waste exchange between maternal and foetal circulations (Watson \& Cross 2005). Defects in placenta development and/ or function have repercussions for foetal growth and health (Watson \& Cross 2005, Perez-Garcia et al. 2018). IVF and/or superovulation in mice are associated with large placentas with reduced vascular density and altered nutrient transport at late gestation to produce normal-sized or growth-restricted fetuses (Delle Piane et al. 2010, Bloise et al. 2012, Weinerman et al. 2017). Indeed, sub-optimally formed placentas might undergo counter-balancing mechanisms leading to adaptive responses (Choux et al. 2015). How and when this dialogue occurs is unclear.

The mechanism through which ART influences the formation and function of the maternal-fetal interface is not well understood. The vast majority of studies have focused on CpG methylation of imprinted genomic loci (Khosla et al. 2001, Mann et al. 2004, Fortier et al. 2008, Rivera et al. 2008, Fauque et al. 2010, Wang et al. 2010, Bloise et al. 2012, de Waal et al. 2014). Genomic imprinting is an epigenetic phenomenon in mammals whereby a small number of genes are expressed in a parent-of-origin-specific manner, a process that is regulated by DNA methylation. Many imprinted genes are expressed in the placenta and are important for its development and function (Tunster et al. 2013). Directed analysis of imprinted regions can act as a convenient read-out of functional DNA methylation changes across the genome (Padmanabhan et al. 2013). Therefore, studies showing altered DNA methylation at imprinted loci after ART hypothesise that these technologies might influence the establishment of DNA methylation genome-wide with consequences for placental cell differentiation (Choux et al. 2015). Dysregulation of other epigenetic mechanisms (e.g., histone modifications, non-coding RNA expression) are largely unstudied in the context of ART.

One procedure that all ARTs have in common is the transfer of the blastocyst into the uterus of a recipient female. While many ART studies in mice have taken into account the potential effects of blastocyst transfer (Kholsa et al. 2001, Delle Piane et al. 2010, Fauque et al. 2010, Bloise et al. 2012), the impact of this procedure alone on placentation site growth and transcription is not well understood. Here, we show that blastocyst transfer in mice has a stark impact on transcriptional regulation and likely influences placental efficiency even as the placenta matures. Furthermore, our genomewide approach enabled us to determine that changes in DNA methylation at proximal promoter regions may not cause transcriptional disruption. Therefore, a long-range study of cis-acting epigenetic mechanisms in addition to DNA methylation is required.

\section{Materials and methods}

\section{Mice}

$\mathrm{C} 57 \mathrm{Bl} / 6$ conceptuses were generated by natural mating of $\mathrm{C} 57 \mathrm{BI} / 6$ mice at 7-10 weeks of age. No hormones were used. $(\mathrm{C} 57 \mathrm{Bl} / 6 \times \mathrm{DBA} / 2) \mathrm{F} 1$ hybrid $(\mathrm{B} 6 \mathrm{D} 2 \mathrm{~F} 1)$ female mice were mated at $7-10$ weeks of age with vasectomized $\mathrm{C} 57 \mathrm{Bl} / 6$ males to generate a pseudopregnant state. B6D2F1 mice have $50 \%$ genetic similarity to $\mathrm{C} 57 \mathrm{Bl} / 6$ mice and were used because C57Bl/6 females are notoriously poor recipients for blastocyst transfer. A broad range of genetic backgrounds has been used for donor and recipient mice across ART studies (Mann et al. 2004, Fortier et al. 2008, Piane et al. 2010, Wang et al. 2010, Chen et al. 2015), including hybrid recipient females as in our study (Kholsa et al. 2001, Fauque et al. 2010, Bloise et al. 2012). C57Bl/6 conceptuses that were derived by natural mating and did not undergo the transfer process were used as controls. Noon of the day that the copulatory plug was detected was considered embryonic (E) day 0.5. Mice were killed via cervical dislocation. All experiments were performed in accordance with the Canadian Council on Animal Care and the University of Calgary Committee on Animal Care (protocol number M06109). This research was also regulated under the Animal (Scientific Procedures) Act 1986 Amendment Regulations 2012 following ethical review by the University of Cambridge Animal Welfare and Ethical Review Body.

\section{Blastocyst transfers}

Conceptuses from the blastocyst transfer experiment were generated as previously described (Padmanabhan et al. 2013). Briefly, using M2 media (Sigma-Aldrich), embryos were flushed at E3.25 from the oviducts and uteri of $\mathrm{C} 57 \mathrm{Bl} / 6$ females. Embryos were cultured in KSOM media (Millipore) microdrops covered in mineral oil (Millipore) at $37^{\circ} \mathrm{C}$ for no more than 30 min. This unavoidable culture period allowed for the surgical preparation of the recipient female. Embryos were transferred by injection into the oviducts of pseudopregnant B6D2F1 recipients 2.5 days after mating them with vasectomized C57Bl/6 males. Litters were never pooled.

\section{Dissections and phenotyping}

All conceptuses were dissected at E10.5. For transferred litters, the timing of dissection corresponded to the staging of the recipient female (Ueda et al. 2003). Implantation sites were dissected away from the uterine myometrium in cold $1 \times$ phosphate buffered saline. Embryos and placentas were rigorously scored for gross phenotypes (see below and Padmanabhan et al. 2013), photographed, weighed, and snap frozen in liquid nitrogen for storage at $-80^{\circ} \mathrm{C}$. Similar to other ART studies on mouse placenta (Fortier et al. 2008, Rivera et al. 2008, Fauque et al. 2010, Wang et al. 2010, Bloise et al. 2012), whole placentas including the mesometrial decidua were assessed. Retaining the decidua is important for sample consistency since reliably removing the decidua without influencing parietal trophoblast giant cell (TGC) numbers is difficult. It also contains invading trophoblast cells (Simmons et al. 2008) that are important to assess. 
For phenotype scoring, defective embryo growth was determined by assessing crown-rump length and somite pairs. Crown-rump lengths that were greater or less than two standard deviations from the mean crown-rump length of C57Bl/6 controls were distinguished as growth enhancement or restriction, respectively. Somite staging was determined according to e-Mouse Atlas Project (http://www.emouseatlas. org): 30-39 somite pairs were considered the normal range for E10.5 and somite pairs <30 indicated developmental delay. Embryos were also assessed for the appearance of haemorrhage, resorptions, twinning, and congenital malformations including defective neural tube closure, abnormal heart loop directionality, and/or presence of pericardial oedema or heart enlargement. Placentas were grossly scrutinized for the presence and orientation of chorioallantoic attachment and haemorrhage. Sex of conceptuses was determined by polymerase chain reaction (PCR) genotyping of yolk sac DNA using reported methods (Chuma \& Nakatsuji 2001, Tunster 2017). Images were obtained using a Zeiss SteREO Discovery V8 microscope with an AxioCam MRc5 camera and AxioVision 4.7.2 software (Carl Zeiss Ltd).

\section{RNA and DNA extraction}

Whole placentas were homogenized using lysing matrix D beads (MP Biomedicals, Carlsbad, USA). For quantitative reverse transcription-PCR (qRT-PCR) analysis, total RNA was extracted using TRIzol reagent (Sigma-Aldrich) according to the manufacturer's instructions. For methylation analysis, DNA and RNA were extracted using the AllPrep DNA/RNA kit (QIAGEN). All RNA extracts were treated with DNAse I (Thermo Scientific).

\section{Transcriptome analysis}

RNA libraries were prepared from whole placentas of nontransferred and transferred $\mathrm{C} 57 \mathrm{Bl} / 6$ conceptuses at E10.5. Four male placentas taken from 3 to 4 litters were assessed per experimental group. Placentas chosen for analysis were associated with phenotypically normal embryos (i.e., the embryos displayed normal crown-rump lengths and somite pair counts and were absent of congenital malformations). Library preparation and sequencing was performed by Cambridge Genomic Services, Department of Pathology, University of Cambridge. The concentration and purity of RNA was determined by a SpectroStar spectrophotometer (BMG LABTECH, Aylesbury, UK) and an Agilent Tapestation Bioanalyzer (Aligent Technologies LDA UK Ltd) determined RNA integrity. Libraries were prepared using 200 ng of total RNA and TruSeq stranded mRNA Library Preparation kit (Illumina, Chesterford, UK). A unique index sequence was added to each RNA library to allow for multiplex sequencing. Libraries were pooled and sequenced on the Illumina NextSeq500 platform with 75-base-pair single-end reads. Sequencing was performed in duplicate to provide $>18$ million reads per sample. To monitor sequencing quality control, 1\% PhiX Control (Illumina) spike-in was used. Quality control of Fastq files was performed using FastQC and fastq_screen. Sequences were trimmed with Trim Galore! and aligned to GRCm38 mouse genome using STAR aligner. Alignments were processed using custom ClusterFlow (v0.5dev) pipelines and assessed using MultiQC (0.9.dev0). Gene quantification was determined with HTSeqCounts (v0.6.1p1). Additional quality control was performed with rRNA and mtRNA counts script, feature counts ( $v$ 1.5.0p2) and qualimap (v2.2). Differential gene expression was performed with DESeq2 package (v1.22.2, R v3.5.2). Read counts were normalised on the estimated size factors. Principle component analysis was performed on the rlog transformed count data for the top 5000 most variable genes. Heatmaps were generated with 'ComplexHeatmap' R package ( $v$ 1.20.0). Karyoplots were generated with karyoploteR (v1.8.8).

\section{Data availability}

The RNA-sequencing data are accessible through ArrayExpress EMBL-EBI accession number E-MTAB-8036. All codes to reproduce the bioinformatics analysis are freely available from https://github.com/CTR-BFX/2019-Menelaou-Watson.

\section{Quantitative reverse transcription-PCR ( $q R T-P C R)$}

Primers were designed using NCBI Primer-BLAST software (Ye et al. 2012). For primer sequences, refer to Supplementary Table 1 (see section on supplementary materials given at the end of this article). Reverse transcription reactions were performed with the RevertAid H Minus reverse transcriptase (Thermo Scientific) and random hexamer primers (Thermo Scientific) using $1 \mu \mathrm{g}$ of total RNA according to manufacturer's instructions. PCR amplification was performed using MESA SYBR Green qPCR MasterMix Plus (Eurogentec, Liege, Belgium) on a DNA Engine Opticon2 thermocycler (BioRad). Transcript levels were normalised to Polr2a RNA and analysed using the comparative $\mathrm{Ct}$ method. cDNA levels in C57Bl/6 control placentas were normalised to 1. For qRT-PCR validation of the RNA-seq experiment, 4-7 whole male or female placentas were analysed per experimental group from 2 to 4 litters and were independent of those assessed by RNA-seq. Experiments were conducted in technical triplicates.

\section{Bisulfite pyrosequencing}

Genomic DNA was bisulphite converted using the Imprint DNA Modification Kit (Sigma-Aldrich) using the one-step modification procedure. Pyrosequencing assays were designed using PyroMark Assay Design SW 2.0 software (QIAGEN). For primer sequences, refer to Supplementary Table 1. PCR was performed in triplicate using HotStarTaq DNA polymerase (QIAGEN) and $5 \mathrm{ng}$ of bisulphite-converted DNA with the following PCR conditions: $95^{\circ} \mathrm{C}$ for $5 \mathrm{~min}$ followed by $95^{\circ} \mathrm{C}$ for $30 \mathrm{~s}, 56^{\circ} \mathrm{C}$ for $30 \mathrm{~s}$ and $72^{\circ} \mathrm{C}$ for $55 \mathrm{~s}$ for 40 cycles, then $72^{\circ} \mathrm{C}$ for $5 \mathrm{~min}$. PCR products were bound to Streptavidin Sepharose High-Performance beads (GE Healthcare) and purified by sequential washing in $70 \%$ ethanol, $0.4 \mathrm{~mol} / \mathrm{L} \mathrm{NaOH}$ and 10 mmol/L Tris-acetate ( $\mathrm{pH}$ 7.6) using a Pyromark Q96 Vacuum Prep Workstation (QIAGEN). The purified product was mixed with the pyrosequencing primer in annealing buffer (20 $\mathrm{mmol} / \mathrm{L}$ Tris-acetate $\mathrm{pH} 7.6,2 \mathrm{mmol} / \mathrm{L}$ magnesium acetate), incubated at $85^{\circ} \mathrm{C}$ for $4 \mathrm{~min}$ and then at room temperature 
for 4 min. Pyrosequencing was conducted using PyroMark Gold reagents (QIAGEN) on a PyroMark MD pyrosequencer (QIAGEN). Analysis of methylation status was performed using Pyro Q-CpG 1.0.9 software (Biotage, Hengoed, UK). The mean $\mathrm{CpG}$ methylation was calculated using five whole female placentas from 3 to 4 litters and at least two technical replicates per experimental group.

\section{Statistical analysis}

Statistical analyses were performed using GraphPad Prism 6 software. Parametric data (e.g., litter sizes, crown-rump lengths, placenta weights, weight ratios) were analysed using $t$ tests. Relative risks were determined to compare males and females of each phenotypic group, and $P$ values were calculated using Fisher's exact test. For the RNA-sequencing data, the nbinomTest was used in $\mathrm{R}$ to calculate the $P$ value and $P$-adjusted value of differentially expressed genes (DEGs). For mRNA expression, data were analysed using Mann-Whitney tests or $t$ tests with Welch correction where appropriate. Pyrosequencing data were analysed using $t$ tests when primers spanned a single CpG site and two-way ANOVA with Sidak's multiple comparisons test when primers spanned two or more $\mathrm{CpG}$ sites. Frequency of CpG repeats was determined using Fisher's exact test. $P<0.05$ was considered significant.

\section{Software and online resources}

Graphs were generated using GraphPad Prism 6 software. DEGs were subject to enrichment analysis using Enrichr (http:// amp.pharm.mssm.edu/Enrichr/) (Chen et al. 2013, Kuleshov et al. 2016). Placental gene expression was determined using the Mouse Encode Project (http://www.mouseencode.org/) (Yue et al. 2014) and Mouse Cell Atlas (http://bis.zju.edu.cn/ MCA/) (Han et al. 2018). Some phenotype data were obtained from Deciphering the Mechanisms of Developmental Disorders database (https://dmdd.org.uk), which is funded by the Wellcome Trust (www.wellcome.ac.uk) with support from the Francis Crick Institute (www.crick.ac.uk) and is licensed under a Creative Commons Attribution license (https://creativecommons.org/licenses/by/4.0/legalcode). CpG islands were identified with the University of California, Santa
Cruz (UCSC) Mouse Genome Browser (http://genome.ucsc. edu/) using NCBI37/mm9 mouse genome assembly of the C57Bl/6 genome (Haeussler et al. 2019). CpG island tracks were defined as a stretch of DNA between 200 and 1300 bp with a GC content $>50 \%$ and a ratio of observed:expected CpG dinucleotides $>0.6$. The enhancer-promoter units (EPUs) were generated according to previously published data (Shen et al. 2012). For this analysis, UCSC Mouse Genome Browser (http://genome.ucsc.edu/) using NCBI37/mm9 mouse genome assembly of the $\mathrm{C} 57 \mathrm{Bl} / 6$ genome (Haeussler et al. 2019) was used to determine $\mathrm{CpG}$ island tracks and to analyse C57BI/6 placenta histone modification peaks from the ENCODE ChIPseq data set (GEO accession: GSM1000133, GSM1000134) (ENCODE Project Consortium 2012, Yue et al. 2014). The $\mathrm{NCBI} 37 / \mathrm{mm} 9$ coordinates were lifted over to GRCm38/ mm10 using LiftOver tool from UCSC. To generate an intersect between DEGs $(\log 2 \mathrm{fc} 1)$ and EPUs, bedtools2 (v2.26.0) software was used. Random gene lists were generated using Random Gene Set Generator (www.molbiotools.com).

\section{Results}

\section{Blastocyst transfer potentially leads to increased placental efficiency at E10.5}

To better understand how blastocyst transfer affects foeto-placental development, we mated C57Bl/6 female mice $(n=10)$ without superovulation to $\mathrm{C} 57 \mathrm{Bl} / 6$ males $(n=10)$. Pre-implantation embryos were flushed at E3.25 from oviducts and uteri of donor females and transferred into oviducts of pseudopregnant B6D2F1 females. Transferred blastocysts were allowed to implant and were dissected at E10.5 (staged according to recipient females (Ueda et al. 2003)) for phenotyping. C57Bl/6 control conceptuses were derived from natural matings, did not undergo the blastocyst transfer procedure, and were dissected at E10.5 for similar analyses.

Prior to transfer, litter sizes at E3.25 ranged between 7 and 10 embryos and included compact morula- and blastocyst-staged embryos (Table 1). Two litters contained at least one embryo with an abnormal appearance (Table 1). However, all embryos were transferred

Table 1 Embryonic phenotypes before and after blastocyst transfer in mice.

\begin{tabular}{|c|c|c|c|c|c|c|c|c|c|c|c|}
\hline \multirow[b]{2}{*}{$\begin{array}{l}\text { Recipient } \\
\text { female ID }\end{array}$} & \multicolumn{4}{|c|}{ Phenotype at E3.5 before transfer } & \multirow{2}{*}{$\begin{array}{c}\text { No. of conceptuses } \\
\text { at E10.5 (implantation } \\
\text { rate }(\%))\end{array}$} & \multicolumn{6}{|c|}{ Phenotype at E10.5 after transfer } \\
\hline & $\begin{array}{c}\text { No. of embryos } \\
\text { transferred }\end{array}$ & $\begin{array}{l}\text { Blastocyst } \\
\text { stage }\end{array}$ & $\begin{array}{l}\text { Morula } \\
\text { stage }\end{array}$ & Abnormal & & PN & GE & GR & DD & $\mathrm{CM}$ & $\mathrm{R}$ \\
\hline C57-T1 & 10 & 5 & 4 & 1 & $6(60.0 \%)$ & 3 & 1 & 0 & 0 & 0 & 2 \\
\hline C57-T2 & 9 & 6 & 3 & 0 & 0 & - & - & - & - & - & - \\
\hline C57-T3 & 10 & 3 & 7 & 0 & $6(60.0 \%)$ & 5 & 0 & 0 & 0 & 0 & 1 \\
\hline C57-T4 & 8 & 4 & 4 & 0 & $4(50.0 \%)$ & 0 & 0 & 0 & 4 & 0 & 0 \\
\hline C57-T5 & 10 & 4 & 3 & 3 & $6(60.0 \%)$ & 6 & 0 & 0 & 0 & 0 & 0 \\
\hline C57-T6 & 9 & 7 & 2 & 0 & $3(33.3 \%)$ & 0 & 1 & 1 & 0 & 0 & 1 \\
\hline C57-T7 & 8 & 7 & 1 & 0 & $5(71.4 \%)$ & 3 & 0 & 1 & 0 & 0 & 1 \\
\hline С57-T8 & 9 & 5 & 4 & 0 & 0 & - & - & - & - & - & - \\
\hline C57-T9 & 8 & 7 & 1 & 0 & $7(87.5 \%)$ & 5 & 1 & 0 & 0 & 0 & 1 \\
\hline C57-T10 & 10 & 6 & 4 & 0 & $6(60.0 \%)$ & 3 & 0 & 0 & 0 & 0 & 3 \\
\hline Total & 91 & 48 & 29 & 4 & $43(47.2 \%)$ & 25 & 3 & 2 & 4 & 0 & 9 \\
\hline
\end{tabular}

CM, congenital malformation; DD, developmentally delayed; E, embryonic day; GE, growth enhanced; GR, growth restricted; PN,

phenotypically normal; $\mathrm{R}$, resorption. 
regardless of appearance. Ten pseudopregnant B6D2F1 females received embryos but only eight were pregnant at E10.5 (80\% efficiency). The average implantation rate was $47.2 \%$ when all transferred litters were considered and $58.9 \%$ when only considering transfers that resulted in pregnancy. Thus, litter sizes in the blastocyst transfer group were significantly smaller $(5.4 \pm 0.5$ implantation sites/litter; $P<0.001)$ than control litters $(9.5 \pm 0.4$ implantation sites/litter) (Table 2). No congenital malformations or gross placental phenotypes were apparent in control or transferred conceptuses at E10.5 (see Methods, Table 2). However, one litter in the transfer group was developmentally delayed since the number of somite pairs in these embryos ranged between 16 and 22 pairs (Fig. 1A) instead of the expected 30-40 somite pairs. At E10.5, 20.9\% of the transferred conceptuses were resorbed compared to only $5.3 \%$ of controls (Table $2)$. Although not statistically significant $(P=0.200)$, this result suggested that blastocyst transfer might lead to increased post-implantation lethality before E10.5. A larger data set is required to explore this finding further.

Overall, male and female conceptuses were present in a 1:1 ratio at E10.5 in both control and transferred groups (Table 2) indicating that sex was not a selective factor on survival after blastocyst transfer. While average embryo weights were similar (Fig. 1B), placental weights were lower in transferred conceptuses compared to controls (Fig. 1C) suggesting that the blastocyst transfer protocol might alter placental development. Furthermore, embryo:placenta weight ratios were higher in transferred conceptuses; yet, only significantly so in transferred female conceptuses $(P=0.025$; Fig. 1D).

To further define the growth phenotype, embryo crown-rump lengths were measured. While mean lengths were not significantly different between control and transfer groups (Fig. 1E), frequency distribution curves of crown-rump lengths were generated (Fig. $1 F)$ to detect specific embryos with abnormal growth. Defective growth was defined as crown-rump lengths that were $>2$ S.D. from the mean length of control embryos. Regardless of sex, a similar frequency of growth restriction was observed in control $(4.4-4.5 \%$ of embryos) and transferred conceptuses at E10.5 (5.9\% of embryos, $P=0.687$; Fig. $1 \mathrm{~A}, \mathrm{~F}$ and Table 2). Interestingly, 3 out of $17(17.6 \%)$ of the transferred male embryos displayed growth enhancement (Fig. 1A, F and Table 2). This frequency was not statistically significant $(P=0.08)$, likely due to the small sample size. No transferred female embryos or control embryos were growth enhanced (Fig. $1 \mathrm{~F}$ and Table 2) suggesting that this phenotype might be sexually dimorphic. A lack of correlation between litter size and crown-rump length in control or transferred litters at E10.5 (Fig. 1G) suggested that litter size is an unlikely confounder of this study.

When all phenotypes (e.g., growth restriction, growth enhancement, developmental delay) and resorptions were grouped together, fewer embryos were classified
Table 2 Phenotypic comparison of non-transferred and transferred mouse conceptuses at E10.5.

\begin{tabular}{|c|c|c|}
\hline & $\begin{array}{l}\mathrm{C} 57 \mathrm{Bl} / 6 \text { non- } \\
\text { transferred }^{*}\end{array}$ & $\begin{array}{l}\mathrm{C} 57 \mathrm{Bl} / 6 \\
\text { transferred }\end{array}$ \\
\hline \multicolumn{3}{|c|}{$\begin{array}{l}\text { No. of conceptuses } \\
\text { assessed at E10.5 }\end{array}$} \\
\hline Total & 95 (10 litters) & 43 (8 litters) \\
\hline Male & $44^{+}$ & $17^{\dagger}$ \\
\hline Female & $45^{+}$ & $17^{+}$ \\
\hline \multicolumn{3}{|c|}{$\begin{array}{l}\text { Average no. of } \\
\text { conceptuses/litter }\end{array}$} \\
\hline Total & $9.5 \pm 0.4$ & $5.4 \pm 0.5^{* * *}$ \\
\hline Male & $4.4 \pm 0.5(46.5 \%)^{\dagger}$ & $2.1 \pm 0.5(39.5 \%)^{\dagger}$ \\
\hline Female & $4.5 \pm 0.4(47.4 \%)^{\dagger}$ & $2.1 \pm 0.5(39.5 \%)^{\dagger}$ \\
\hline \multicolumn{3}{|l|}{ Phenotypes } \\
\hline \multicolumn{3}{|c|}{$\begin{array}{c}\text { Phenotypically } \\
\text { normal }\end{array}$} \\
\hline Total & $8.6 \pm 0.5(90.5 \%)$ & $3.1 \pm 0.8^{* * *}(58.1 \%)$ \\
\hline Male & $4.2 \pm 0.5(95.5 \%)$ & $1.3 \pm 0.5^{* * *}(58.8 \%)$ \\
\hline Female & $4.1 \pm 0.4(91.1 \%)$ & $1.9 \pm 0.5^{* * *}(88.2 \%)$ \\
\hline \multicolumn{3}{|c|}{ Growth enhanced } \\
\hline Total & 0.0 & $0.4 \pm 0.2^{\ddagger}(7.0 \%)$ \\
\hline Male & 0.0 & $0.4 \pm 0.2^{\ddagger}(17.6 \%)$ \\
\hline Female & 0.0 & 0.0 \\
\hline \multicolumn{3}{|c|}{ Growth restricted } \\
\hline Total & $0.4 \pm 0.2(4.2 \%)$ & $0.3 \pm 0.2(4.7 \%)$ \\
\hline Male & $0.2 \pm 0.1(4.5 \%)$ & $0.1 \pm 0.1(5.9 \%)$ \\
\hline Female & $0.2 \pm 0.1(4.4 \%)$ & $0.1 \pm 0.1(5.9 \%)$ \\
\hline \multicolumn{3}{|c|}{ Developmental delay } \\
\hline Total & 0.0 & $0.5 \pm 0.5(9.3 \%)$ \\
\hline Male & 0.0 & $0.4 \pm 0.4(17.6 \%)$ \\
\hline Female & 0.0 & $0.1 \pm 0.1(5.9 \%)$ \\
\hline \multicolumn{3}{|c|}{$\begin{array}{l}\text { Congenital } \\
\text { malformations }\end{array}$} \\
\hline Total & 0.0 & 0.0 \\
\hline Male & 0.0 & 0.0 \\
\hline & 0.0 & 0.0 \\
\hline \multicolumn{3}{|c|}{ Resorptions $^{\dagger}$} \\
\hline Total & $0.5 \pm 0.3(5.3 \%)$ & $1.1 \pm 0.4(20.9 \%)$ \\
\hline Male & - & - \\
\hline Female & - & - \\
\hline
\end{tabular}

*Data are presented as average number of conceptuses ( \pm S.E.) per litter unless otherwise indicated. Number in brackets indicates the percentage of total conceptuses with each phenotype. ${ }^{\dagger}$ Resorptions could not be genotyped for sex due to maternal tissue contamination. ${ }^{\ddagger} P=0.08$.

as 'phenotypically normal' (PN) in the transferred group (55.8\%; $P<0.001)$ compared to controls $(91.6 \%$; Table 2 ). When the analysis was restricted to conceptuses with PN embryos (Fig. 1A and F), average weight of the associated placentas remained lower in transferred conceptuses compared to controls, regardless of sex $(P<0.004$; Fig. 1J). Despite this, average embryo weight was normal in $\mathrm{PN}$ males $(P=0.472)$ and higher in $\mathrm{PN}$ females $(P=0.019)$ compared to same-sex controls (Fig. 1I). These data suggested that the placentas of transferred conceptuses, though small, were potentially more efficient in both sexes. This hypothesis was reinforced by increased embryo:placenta weight ratios in PN transferred conceptuses $(P<0.002$; Fig. $1 \mathrm{~K})$. Future histological and functional analyses are required to confirm this hypothesis. Altogether, these data imply that 
A Non-transferred

Transferred
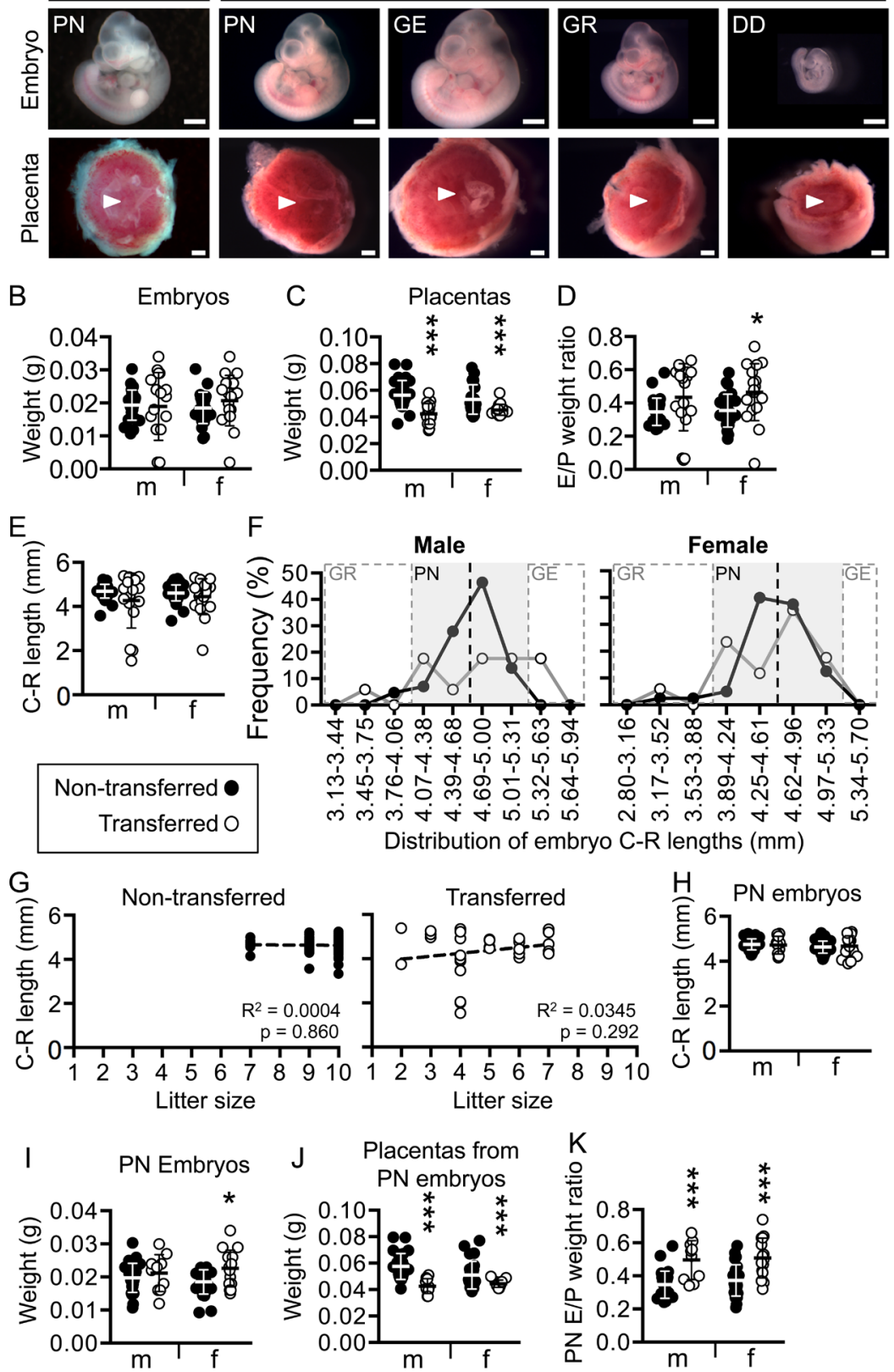

Figure 1 Blastocyst transfer in mice results in small placentas with a potential for increased efficiency at E10.5. (A) Images of embryos and placentas from non-transferred and transferred conceptuses at E10.5. Embryonic phenotypes shown include phenotypically normal (PN), growth enhanced (GE), growth restricted (GR), and developmentally delayed (DD) as determined by crown-rump lengths and somite pair counts. Arrowhead indicates where the allantois (i.e. the umbilical cord) was attached to the placenta. Scale bars: $500 \mu \mathrm{m}$. (B, C, D and E) Graphs showing (B) embryo weights, (C) placenta weights, (D) embryo:placenta (E/P) weight ratios, and (E) embryo crown-rump (CR) lengths in all non-transferred (black circles) and transferred (white circles) conceptuses at E10.5. Values are shown for male $(\mathrm{m})$ and female $(\mathrm{f})$ conceptuses $(n=17-43)$ and data are presented as mean \pm S.D. Independent $t$ test, $* P<0.05,{ }^{*} * P<0.001$. (F) Frequency distribution curves of embryo CR lengths as determined by sex for non-transferred (black solid line) and transferred (grey solid line) embryos. Only embryos staged as E10.5 were considered. Black dotted lines indicate the mean crown-rump length for non-transferred embryos. Lengths that fall within the grey shading indicate conceptuses that are grossly phenotypically normal (PN). Grey dotted lines indicate two s.D.s from the control mean. Crown-rump lengths that were greater than two S.D.s below the mean were considered GR and greater than two S.D.s above the mean were considered GE. (G) Linear regression analysis of litter size versus embryo CR length in control (black circles) and transferred (white circles) conceptuses. A line of best fit is indicated (dotted line). ( $\mathrm{H}, \mathrm{I}, \mathrm{J}$ and $\mathrm{K}$ ) Graphs showing parameters for PN conceptuses only including (H) embryo CR length, (I) embryo weight, (J) placenta weight, and (K) E/P weight ratios in non-transferred (black circles) and transferred (white circles) conceptuses. Data are presented as mean \pm S.D. and is shown for male $(\mathrm{m})$ and female $(\mathrm{f})$ conceptuses $(n=10-43$ conceptuses). Independent $t$ tests, $P<0.05$, $* * * P<0.001$. 
after blastocyst transfer, normal growth trajectory of the embryo is likely reliant upon functional compensation by the placenta.

\section{Blastocyst transfer alters the placental transcriptome at E10.5}

Typically, large litters result in smaller conceptuses, particularly in late gestation when competition for maternal resources is highest (Ishikawa et al. 2006). In our data at E10.5, we observed that neither embryo crown-rump length (Fig. 1G) nor placenta weight (Fig. 2A) correlated with litter size. These data further demonstrate that litter size is an unlikely confounder in our study.

We sought to determine the effect of blastocyst transfer on the placental transcriptome. A genomewide transcriptome analysis was performed via RNA sequencing to determine differential mRNA expression in whole placentas from control $(n=4)$ or transferred $(n=4) \mathrm{C} 57 \mathrm{Bl} / 6$ conceptuses at E10.5. Since the placenta transcriptome is known to exhibit some sexual dimorphism (Gonzalez et al. 2018) and due to tissue availability, only male placentas associated with PN embryos were selected for analysis. cDNA libraries generated from placental RNA were sequenced using the NextSeq500 (Illumina) platform and bioinformatically analysed.

A principal component analysis revealed that, based on RNA content, the placentas of control and transferred conceptuses clustered separately (Fig. 2B). Differential mRNA expression was determined when $\log _{2}$ (fold change) $>1$ (i.e. fold change $\geq 2 ; P<0.05$ ). Remarkably, 543 genes were differentially expressed in transferred placentas compared to controls including 355 upregulated and 188 downregulated genes (Fig. 2C and D). We selected 27 (5.0\%) DEGs for validation via qRTPCR using RNA isolated from independent whole male placentas ( $n=4-7$ placentas/group) (Figs 2E, F and 4B). Thirteen out of 17 genes that were downregulated in the RNA-sequencing experiment were also downregulated in the qRT-PCR analysis $(P<0.05)$, with the remaining four genes showing a strong downward trend (Figs $2 \mathrm{E}$ and $4 \mathrm{~B}$ ). Furthermore, eight out of ten upregulated genes were also statistically validated by qRT-PCR $(P<0.05$; Figs $2 \mathrm{~F}$ and $4 \mathrm{~B})$. Therefore, the RNA-sequencing experiment was deemed robust and reliable.

\section{All major placental cell types represented by differentially expressed genes}

To determine if blastocyst transfer affected gene expression in specific placental cell types, we performed an extensive literature and database search to resolve the spatial expression of the DEGs in mouse placentation sites. The primary resource for this analysis was a published single-cell RNA sequencing data set on whole
C57Bl/6 mouse placentas at E14.5 (Han et al. 2018). Although the developmental stage assessed in Han et al. (2018) differed slightly from our analysis, the data can be used as a predictive indicator of spatial expression.

Of the 543 DEGs that were identified, placental expression of the majority of DEGs (362 genes) is not currently described in mouse. Expression of 102 DEGs has been reported in the $\mathrm{C} 57 \mathrm{BI} / 6$ mouse placenta at term but without information about cell type specificity (Yue et al. 2014) (Supplementary Table 2). Spatial expression of the remaining 79 genes has been characterized. In several cases (14 DEGs), gene expression occurred in more than one placental cell population (Fig. 3A and Supplementary Table 3). Additionally, most cell types present in the mouse placentation site were represented by DEGs (e.g., trophoblast, endothelial, endoderm, stromal, decidual, hematopoietic lineages) (Fig. 3A and Supplementary Table 3) further indicating that blastocyst transfer is unlikely to affect a single cell lineage. A similar proportion of DEGs were detected in trophoblast cells (26/79 DEGs, 32.9\%) and endodermal cells (27/79 DEGs, 34.2\%), though fewer DEGs were detected in the decidua (19/79 DEGs, 24.1\%) and foetal vascular endothelium (5/79, DEGs, 6.3\%) (Fig. 3A and Supplementary Table 3). It will be important in the future to validate the spatial expression of these genes in the mouse placentation site at E10.5 using in situ hybridisation. Overall, this result suggested that blastocyst transfer caused broad transcriptional changes throughout the mouse placentation site at midgestation even when the embryo was considered phenotypically normal.

\section{DEGs were enriched for genes associated with placental growth and function}

The primary annotation terms enriched in placentas from transferred conceptuses at E10.5 included genes important for placental development, growth and function (Fig. 3B). Enrichment groups included genes associated with specific mammalian phenotypes (e.g., decreased vascular permeability, abnormal visceral yolk sac, abnormal lipid and glucose homeostasis, and decreased circulating IGF1 and insulin levels), and genes required for specific biological processes (e.g., cell adhesion, response to decreased oxygen levels, and negative regulation of cell proliferation and growth) (Fig. 3B). At least 13 DEGs identified are important for placental development and/or function as evidenced by gene knockout and overexpression studies (Table 3). Furthermore, 31 DEGs encode for proteins with nutrient transporter activity (24/31 (77.4\%) DEGs were upregulated; $7 / 31$ (22.6\%) DEGs were downregulated) including gap junction protein 1 (Gjb1), and those important for lipid and fatty acid transport (Slc27a2, Mttp, Apom, Amn) and glutamate transport (Slc17a8, Slc7a11) (Table 4). Together, these data supported the 
A
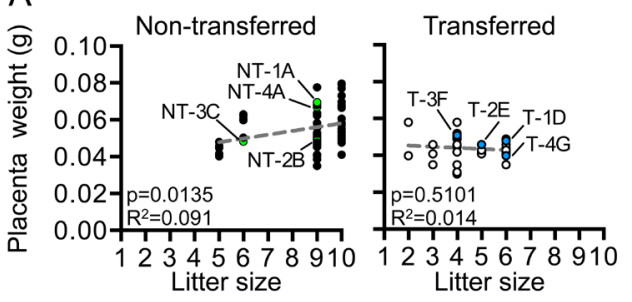

B

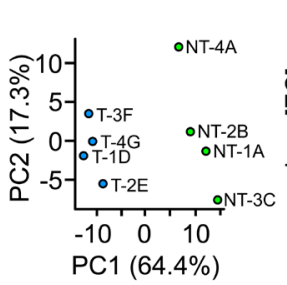

C

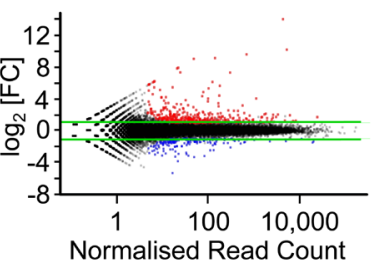

E

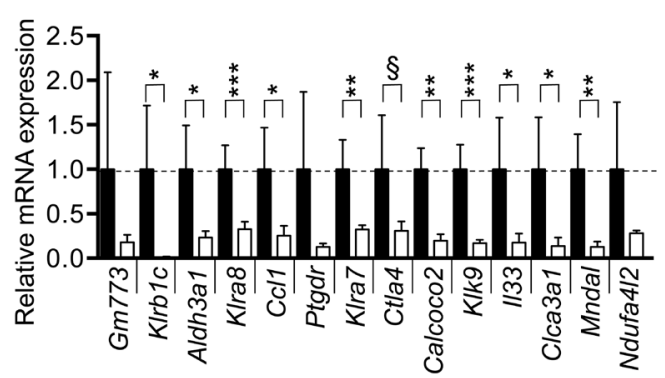

F

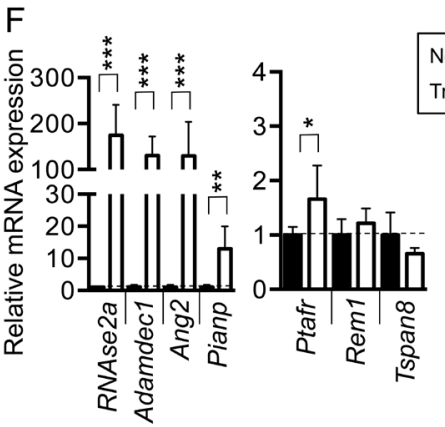

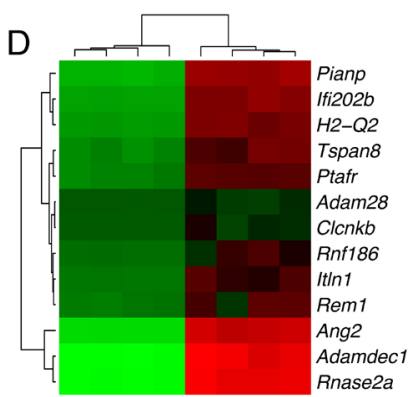

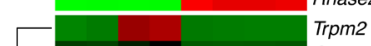

Trpm

AU022751

Dazl

Calcoco2

KIk9

KIra4

Girp1

Ptgdr

KIrb1c

Clca3a1

G530011006Rik

Gm773

KIra8

Mndal

Ctla4

Aldh3a1

KIra7

Ndufa4/2

Cobl

Rasgrf1

Zfp36/1

Crabp2

Slpi

Enpp2

$\mathrm{Cp}$

Igf1

Slc9a2

F2

Cubn

Rpgrip1

1133

Tac2

Prl7a1

Prlat
Prlac2
Prl8a1

Prisa
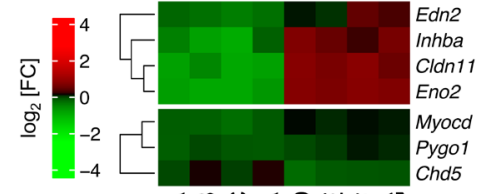

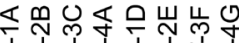

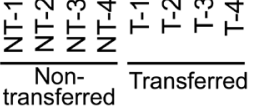

Figure 2 Blastocyst transfer causes differential gene expression in mouse placentas at E10.5. An RNA-seq analysis was performed on whole male placentas from non-transferred and transferred experimental groups. $n=4$ placentas from 3 to 4 litters per group were analysed. Placentas assessed via RNA-seq are labeled in panels A, B, C and D with the placenta ID (non-transferred (NT) or transferred (T) followed by the sample number and letter ID indicating the litter). (A) Graphs plotting litter size versus placental weight of male and female non-transferred placentas (left panel) and transferred placentas (right panel). The line of best fit (grey dotted line) is indicated, and the $P$ and $R^{2}$ values from a linear regression analysis are shown. Green and blue data points are samples used in the RNA-seq experiment. (B) Principal component analysis of the RNA-seq data of whole male placentas from control non-transferred (green circles) and transferred (blue circles) conceptuses. (C) MA plot revealing 543 differentially expressed genes (DEGs) with a fold change $>\log _{2} 1.0$ (i.e., fold change $\geq 2 ; P<0.05$ ) in placentas from transferred conceptuses compared to non-transferred controls. 188 DEGs were downregulated (blue) and 355 DEGs were upregulated (red). (D) Heat map showing differential expression of selected DEGs in non-transferred (NT) and transferred (T) placentas. Scale shown is $\log _{2}$ (fold change). Red, gene upregulation; green, gene downregulation. (E and F) Validation of RNA-seq data by qRT-PCR analysis in independent placentas from non-transferred (black bars) and transferred (white bars) conceptuses. Data are presented as fold change compared to controls (normalised to 1). $n=4-7$ placentas per group from 2 to 4 litters. Graphs show qRT-PCR data of representative genes that were significantly (E) downregulated or (F) upregulated in transferred placentas. Unpaired $t$ tests with Welch correction or Mann-Whitney tests where appropriate, ${ }^{\circledR} P=0.05,{ }^{*} P<0.05$, ${ }^{* *} P<0.01,{ }^{* * *} P<0.001$. 


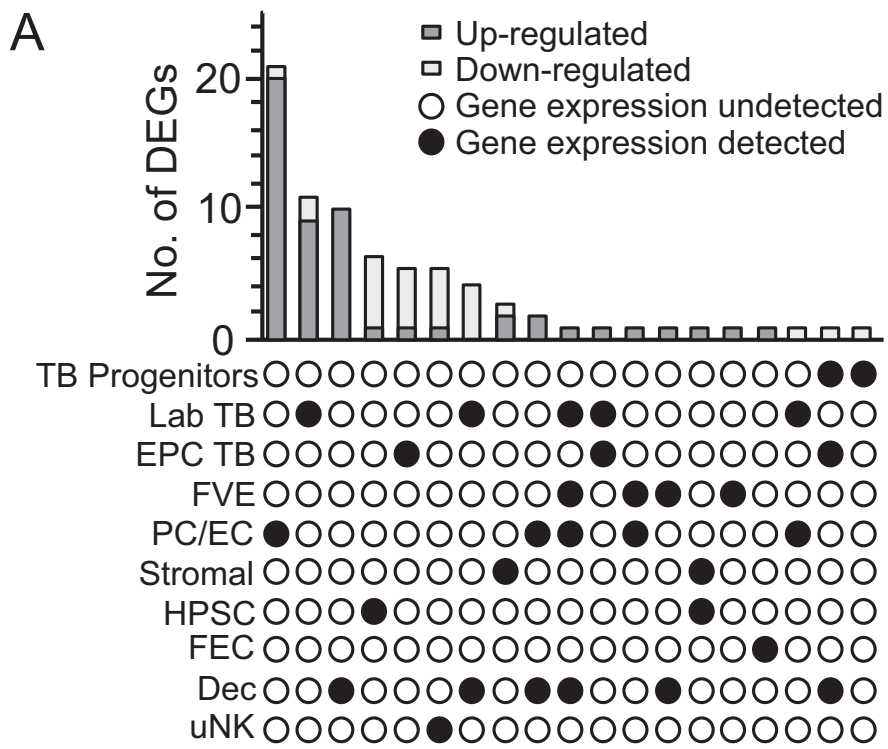

Cell type

B

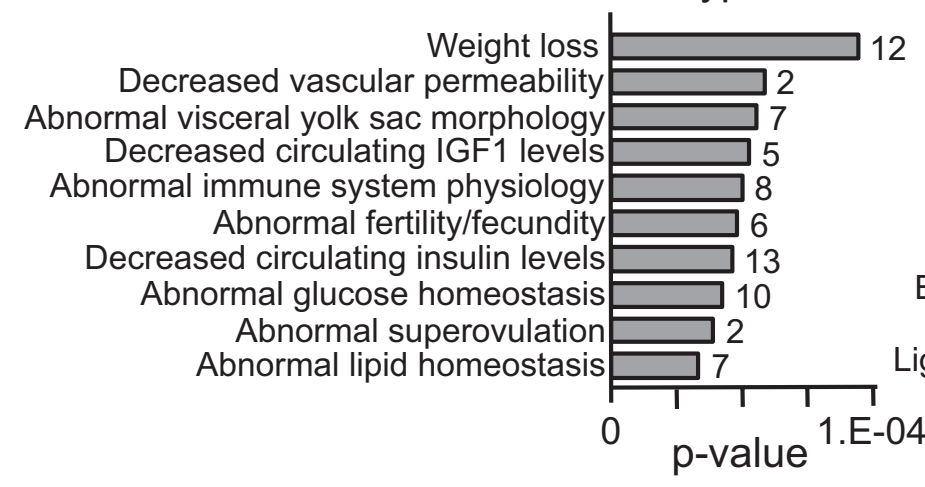

\section{GO: Biological processes}

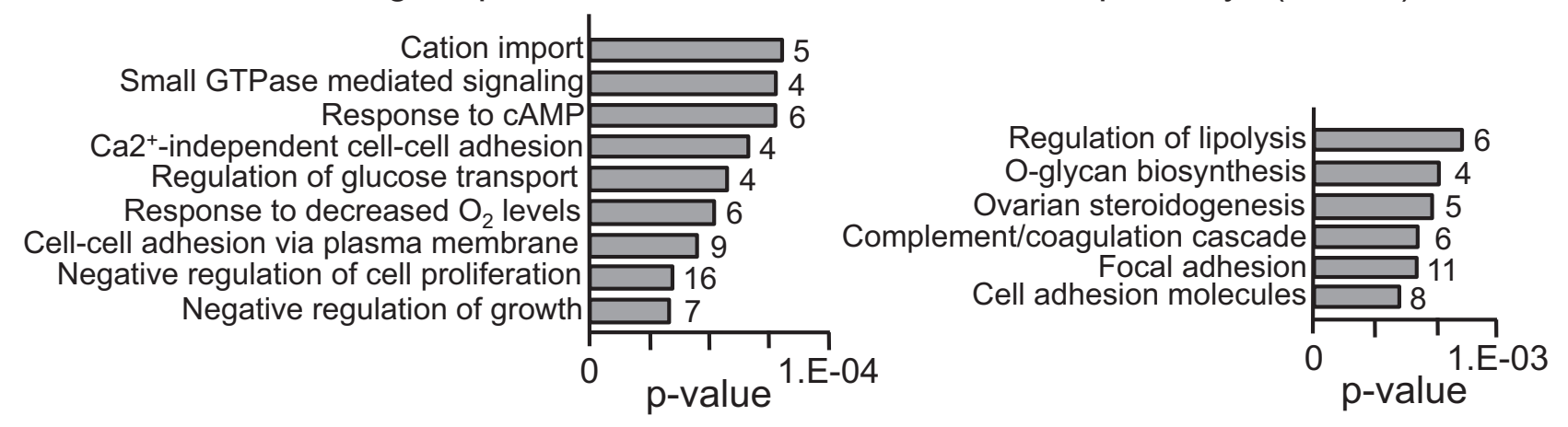

GO: Molecular functions

2

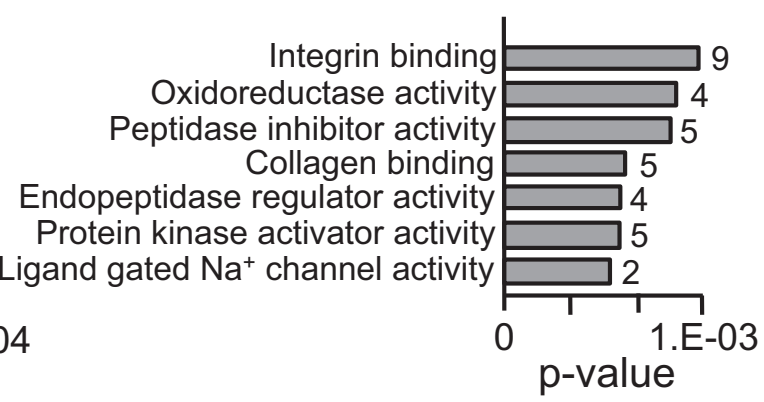

KEGG pathways (DAVID)

Figure 3 Spatial expression and ontological analyses of DEGs identified in placentas of transferred mouse conceptuses at E10.5. (A) UpsetR plot summarizing the predicted spatial expression of 79 DEGs in the mouse placentation site. Data were largely obtained from a published single-cell RNA sequencing data set on whole mouse placenta at E14.5 (Han et al. 2018). See also Supplementary Table 3. Dark grey bars, upregulated DEGs; light grey bars, downregulated DEGs; black circles indicate cell-specific expression; white circle indicates that expression was undetected. TB, trophoblast; Lab TB, labyrinth trophoblast; EPC TB, ectoplacental cone trophoblast; FVE, fetal endothelial vascular cells; PE/ EC, parietal endoderm or endodermal cells; HPSC, haematopoietic stem cells; FEC, foetal erythroid cell; Dec, decidua; uNK, uterine natural killer cell. (B) Gene ontology term enrichment analysis for DEGs in placentas of transferred conceptuses. The numbers of genes in each term are also given. 
Table 3 Differentially expressed genes in placentas of transferred mouse conceptuses at E10.5 that are implicated in growth, placental phenotypes, and/or embryonic lethality.

\begin{tabular}{|c|c|c|c|c|}
\hline Gene & Gene function & $\begin{array}{l}\text { Mouse-knockout phenotype or clinical } \\
\text { characteristics (timing of embryonic lethality) }\end{array}$ & Reference & FC \\
\hline \multicolumn{5}{|c|}{ Genetic knockout or decreased expression: defective labyrinth, placental insufficiency and/or FGR } \\
\hline Cubn & Receptor-mediated endocytosis & Defects in chorioallantoic attachment (E10.5) & (Smith et al. 2006) & 2.9 \\
\hline Enpp2 & Angiogenesis & Defective chorioallantoic attachment (E10.5) & (Fotopoulou et al. 2010) & 2.5 \\
\hline Zfp36/1 & RNA-binding protein & $\begin{array}{l}\text { Failure of chorioallantoic attachment }{ }^{\dagger} \text {, reduced } \\
\text { branching morphogenesis in labyrinth layer, } \\
\text { small spongiotrophoblast layer }\left(\mathrm{E} 10.5^{\dagger}\right)\end{array}$ & $\begin{array}{l}\text { (Stumpo et al. 2004, } \\
\text { Bell et al. 2006) }\end{array}$ & 2.1 \\
\hline$F 2$ & Maintenance of vascular integrity & $\begin{array}{l}\text { Reduced or absent branching morphogenesis } \\
\text { in labyrinth layer }\left(\mathrm{E} 10.5^{+}\right)\end{array}$ & $\begin{array}{l}\text { (Sun et al. 1998, } \\
\text { Xue et al. 1998) }\end{array}$ & 3.4 \\
\hline Rpgrip 1 & Regulator of ciliary protein traffic & $\begin{array}{l}\text { Abnormal vasculature in labyrinth at E14.5 } \\
\text { ('Pre-weaning' lethality) }\end{array}$ & $\begin{array}{l}\text { (Perez-Garcia et al. } \\
\text { 2018) }\end{array}$ & -2.0 \\
\hline Slpi & Serine protease inhibitor & $\begin{array}{l}\text { Downregulated expression in rat model of } \\
\text { placental insufficiency (ND) }\end{array}$ & (Goyal et al. 2010) & 2.5 \\
\hline $\operatorname{lgf1}$ & Insulin-like growth factor & $\begin{array}{l}\text { Severely growth restricted; unknown placental } \\
\text { phenotype (Perinatal) }\end{array}$ & (Liu \& LeRoith 1999) & 2.2 \\
\hline \multicolumn{5}{|c|}{ Increased gene expression: trophoblast phenotype, placental insufficiency, preeclampsia, or FGR } \\
\hline Aldh3a1 & Aldehyde dehydrogenase & $\begin{array}{l}\text { OE in mouse TSCs prevents differentiation into } \\
\text { Tpbpa+ cells (EPC lineage) (ND) }\end{array}$ & $\begin{array}{l}\text { (Nishiyama et al. } \\
\text { 2015) }\end{array}$ & -9.3 \\
\hline $1 / 33$ & Interleukin & $\begin{array}{l}\text { Inhibits trophoblast invasion and } \\
\text { adhesion in vitro (ND) }\end{array}$ & (Wang et al. 2017) & -4.0 \\
\hline Tac2 & Disintegrin and metalloproteinase & $\begin{array}{l}\text { Fetal growth restriction in humans associated } \\
\text { with increased placental expression (ND) }\end{array}$ & (Ozler et al. 2016) & -3.1 \\
\hline Crabp2 & Retinoic acid signalling pathway & $\begin{array}{l}\text { OE in endometrial cell line causes decreased } \\
\text { proliferation of trophoblast spheroids (ND) }\end{array}$ & (Lee et al. 2011) & 2.3 \\
\hline$C p$ & Iron peroxidase & $\begin{array}{l}\text { Increased placental expression associated } \\
\text { with pre-eclampsia in humans (ND) }\end{array}$ & (Guller et al. 2008) & 2.6 \\
\hline Slc9a2 & Sodium/hydrogen exchanger & 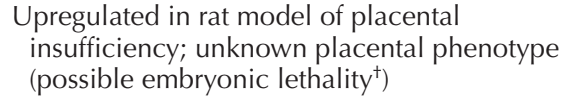 & (Goyal et al. 2010) & 2.9 \\
\hline
\end{tabular}

${ }^{\dagger}$ Incomplete penetrance.

E, embryonic day; EPC, ectoplacental cone; FC, fold change in RNA-sequencing experiment; FGR, foetal growth restriction; ND, not determined; OE, overexpression; TSCs, trophoblast stem cells.

hypothesis that blastocyst transfer results in structural and functional compensation by the placenta with the aim of maintaining embryo growth. Whether changes in gene expression lead to altered protein expression or activity in transferred placentas requires exploration.

\section{Dysregulation of DNA methylation at proximal promoter regions by blastocyst transfer is unlikely to disrupt transcription}

The mechanism by which blastocyst transfer alters gene expression is not well understood, though epigenetic dysregulation has been implicated (Choux et al. 2015, Canovas et al. 2017). To examine the potential sensitivity of the DEGs to changes in DNA methylation, we first evaluated whether the top 50 downregulated genes (fold change >3.1) and top 50 upregulated genes (fold change >6.7) contained intragenic CpG islands or proximal promoter $\mathrm{CpG}$ islands (within 20 $\mathrm{kb}$ of the gene) (Fig. 4A). This result was compared to 50 randomly selected genes as a proxy for the rest of the genome. CpG islands are usually associated with methylation and are known to regulate gene expression (Gardiner-Garden \& Frommer 1987). We identified CpG islands using the CpG island track within the UCSC Mouse Genome Browser (Haeussler et al. 2019; see
Methods). While this initial analysis did not determine whether the CpG islands were methylated or directly regulate gene expression, it highlighted the potential for gene dysregulation when methylation patterns are altered. Compared to the genome, both up and downregulated gene sets were less likely to contain intragenic CpG islands (22-30\% of DEGs compared of $55 \%$ of genes genome-wide, $P<0.005$; Fig. 4A). Moreover, downregulated DEGs were less frequently associated with proximal promoter CpG islands $(26 \%$ of DEGs, $P=0.025$ ) than both upregulated DEGs and the genome $(42 \%$ of genes; Fig. $4 \mathrm{~A})$. Overall, these findings suggested that genes that were differentially expressed after blastocyst transfer were less likely to be cis-regulated by intragenic or proximal promoter $\mathrm{CpG}$ methylation compared to the genome at large.

We identified 15 DEGs whose regulation was directly linked to CpG methylation at specific genomic locations by other studies (Table 5). Based on the published data and our RNA-seq results, we predicted that seven of these DEGs should be associated with CpG hypomethylation and eight DEGs with CpG hypermethylation (Table 5). We sought to test CpG methylation in two loci (e.g., Prl3d1 promoter and the differentially methylated region (DMR) associated with the Rasgrf1 gene) via bisulfite pyrosequencing. Due to tissue availability, bisulfite 
Table 4 Differentially expressed genes in placentas of transferred mouse conceptuses at E10.5 that encode for proteins with transporter function.

\begin{tabular}{|c|c|c|}
\hline Gene & $\begin{array}{c}\text { Fold } \\
\text { change }\end{array}$ & Gene function \\
\hline \multicolumn{3}{|c|}{ Downregulated genes } \\
\hline Trpm2 & -10.1 & Calcium channel \\
\hline $\begin{array}{l}\text { Slc28a2l } \\
\quad(G m 14085)\end{array}$ & -5.15 & Purine nucleoside transporter \\
\hline Clca3a1 & -3.90 & $\begin{array}{l}\text { Calcium-activated chloride } \\
\text { channel }\end{array}$ \\
\hline S/c $17 a 8$ & -3.00 & L-glutamate transporter \\
\hline Ndufa4/2 & -2.93 & $\begin{array}{l}\text { NADH dehydrogenase } \\
\text { (ubiquinone), mitochondria }\end{array}$ \\
\hline Slc28a2 & -2.03 & $\begin{array}{l}\text { Sodium-coupled purine } \\
\text { nucleoside transporter }\end{array}$ \\
\hline Kcnab2 & -2.03 & $\begin{array}{l}\text { Voltage-gated potassium } \\
\text { channel, NADH oxidation }\end{array}$ \\
\hline \multicolumn{3}{|c|}{ Upregulated genes } \\
\hline KCnd2 & 5.13 & Voltage-gated potassium channel \\
\hline Kcne3 & 3.91 & Voltage-gated potassium channel \\
\hline Kcnj12 & 3.07 & $\begin{array}{l}\text { ATP-sensitive inward rectifier } \\
\text { potassium channel }\end{array}$ \\
\hline Atp6v1c2 & 2.89 & $\begin{array}{l}\text { Proton-exporting ATPase, } \\
\text { phosphorylative mechanism }\end{array}$ \\
\hline S/C9a2 & 2.87 & Sodium/hydrogen exchanger \\
\hline Slc13a5 & 2.87 & $\begin{array}{l}\text { Sodium-dependent citrate } \\
\text { transporter }\end{array}$ \\
\hline Gjb1 & 2.84 & Gap junction protein \\
\hline Slc7a9 & 2.72 & $\begin{array}{l}\text { Sodium-independent L-cystine } \\
\text { transporter }\end{array}$ \\
\hline Abcc6 & 2.68 & ATP-binding cassette transporter \\
\hline Cftr & 2.62 & ATP-gated chloride channel \\
\hline Slc27a2 & 2.60 & Fatty acid transporter \\
\hline Hen4 & 2.58 & $\begin{array}{l}\text { Cyclic nucleotide-gated } \\
\text { potassium channel }\end{array}$ \\
\hline Slc7a11 & 2.57 & Cysteine/glutamine transporter \\
\hline Cacna1b & 2.56 & Voltage-gated calcium channel \\
\hline Jph2 & 2.42 & Calcium channel \\
\hline S/c39a8 & 2.31 & Zinc ion transporter \\
\hline Trpm3 & 2.31 & Cation channel \\
\hline Mttp & 2.30 & $\begin{array}{l}\text { Microsomal triglyceride transfer } \\
\text { protein }\end{array}$ \\
\hline Kcnk2 & 2.21 & Potassium channel \\
\hline Asic2 & 2.14 & Voltage-gated sodium channel \\
\hline Apom & 2.09 & Lipid transport \\
\hline Scnn1g & 2.07 & $\begin{array}{l}\text { Amiloride-sensitive sodium } \\
\text { channel }\end{array}$ \\
\hline Amn & 2.04 & Cobalamine and lipid transport \\
\hline Slc4a1 & 2.03 & Chloride/bicarbonate exchanger \\
\hline
\end{tabular}

pyrosequencing was carried out on whole female placentas ( $n=5$ placentas from 3 to 4 litters/group), even though the RNA-sequencing experiment assessed whole male placentas. To rectify potential sex differences, we first verified that female placentas from transferred conceptuses showed similar dysregulation of DEGs as male transferred conceptuses by performing qRT-PCR analysis. In all six DEGs assessed (i.e., Prl3d1, Rasgrf1, Dazl, Cldn11, Tfpi2, Eno2), female and male transferred placentas showed similar patterns of gene misexpression relative to same-sex controls (Fig. 4B). Thus, regardless of sex, we expected CpG hypermethylation in the Pr/3d1 promoter (Hayakawa et al. 2012) (Fig. 4C) in transferred placentas since Prl3d1 mRNA expression was low (Figs 2D and 4B). Nevertheless, five CpG sites across the Pr/3d1 promoter revealed comparable levels of methylation in non-transferred and transferred placenta groups (Fig. 4D). This methylation pattern was also similar to normal $\mathrm{C} 57 \mathrm{Bl} / 6 \mathrm{~N}$ placentas without decidua at E14.5 (Hayakawa et al. 2012) indicating that the presence of decidua in our placentas was an unlikely confounder. Likewise, we assessed CpG methylation in the Rasgrf1 DMR (Fig. 4C). Reduced Rasgrf1 mRNA expression in transferred placentas (Figs 2D and 4B) intimated that hypomethylation of the Rasgrf1 DMR was expected (Yoon et al. 2005). However, four out of five CpGs assessed showed similar levels of methylation in transferred and control placentas (Fig. 4E). One CpG site in the Rasgrf1 DMR (CpG-5) was hypomethylated in transferred placentas $(20.7 \pm 4.1 \%$ methylated vs $38.6 \pm 4.0 \%$ methylated in controls; $P<0.0001$; Fig. $4 \mathrm{E})$, but hypomethylation of a single CpG among many is unlikely to be responsible for increased Rasgrf 1 mRNA expression. Altogether, these data supported the hypothesis that disruption of DNA methylation at promoter regions by blastocyst transfer might not lead to transcriptional changes in the mouse placenta at E10.5.

\section{Some DEGs cluster in the genome implying common transcriptional regulation}

Next, we determined the chromosomal location of DEGs (fold change $>2$ ) including 355 upregulated and 188 downregulated genes (Fig. 5A). While the DEGs were distributed throughout the genome, we observed several genomic clusters of two or more DEGs (Fig. $5 \mathrm{~A})$. Gene clustering was unlikely to occur by chance because no clusters were identified in a group of 60 randomly selected genes. This observation suggested that some DEGs might share common long-range, cis-acting regulatory mechanism(s). To explore this hypothesis further, we analysed a published data-set that defined enhancer-promoter units (EPUs) in C57Bl/6 placentas at term based on an active chromatin state at enhancers (i.e., enrichment for $\mathrm{H} 3 \mathrm{~K} 4$ monomethylation (me1) and H3K27 acetylation (ac)) and occupancy of RNA polymerase II at promoters (Shen et al. 2012). From these data, we predicted DEGs (fold change $>2$ ) that were coordinately regulated by cis-acting elements in the placenta based on their EPU co-localisation. A total of 33 EPUs were identified containing at least two DEGs and a maximum of eight DEGs (mean ( \pm S.D.): $2.6 \pm 1.4$ DEGs/EPU; Fig. 5A, B and Supplementary Table 4). We found that $15.8 \%$ (86/543) of DEGs fell within shared EPUs and, in general, all DEGs within a single EPU showed a similar direction of misexpression (Supplementary Table 4). This finding supported the hypothesis of shared long-range, cis-acting regulation of some DEGs and highlighted the potential importance of histone modifications in this process. Chromatin 
A

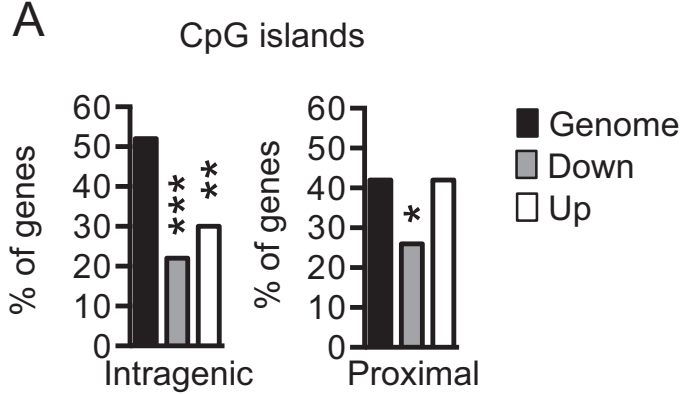

C
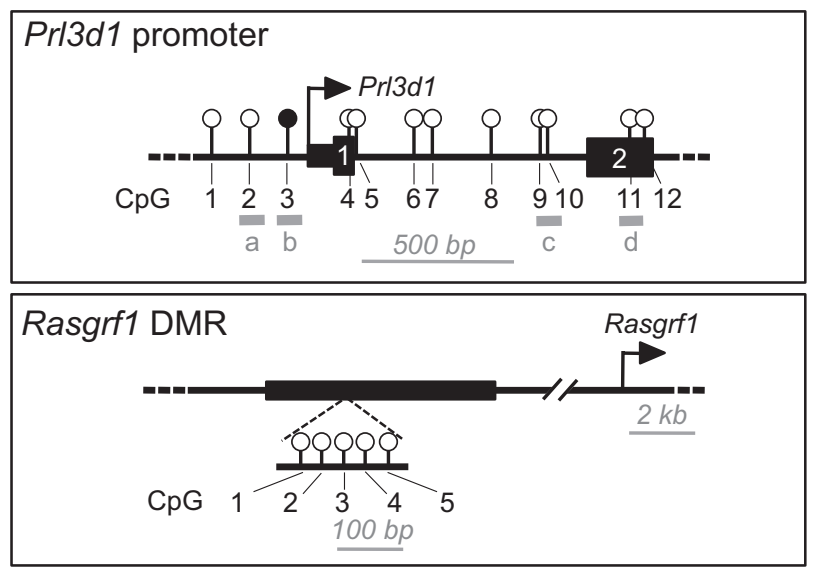
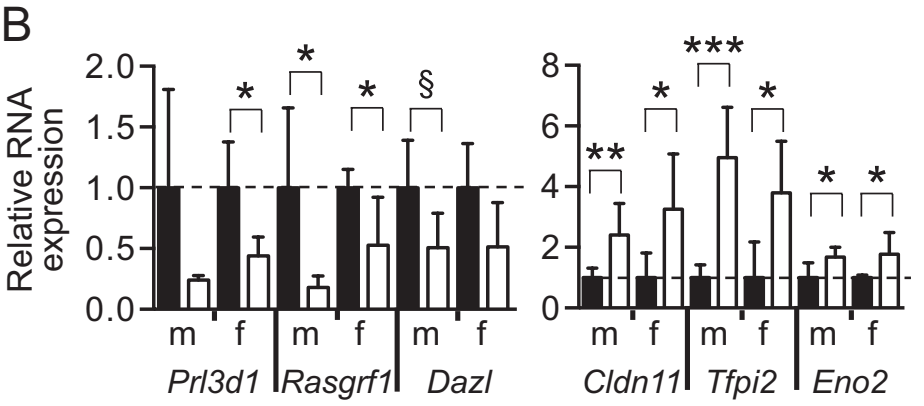

- Control aTransferred
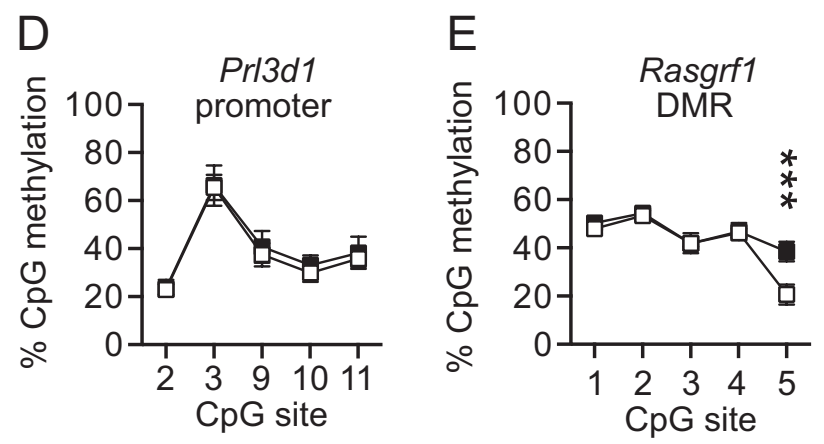

- Control aTransferred

Figure 4 Alteration of proximal promoter $\mathrm{CpG}$ methylation might not disrupt transcriptional change in the mouse placenta after blastocyst transfer. (A) The percentage of the top 50 downregulated DEGs (grey bars, FC >3.1) or upregulated DEGs (white bars, FC >6.7) after blastocyst transfer that associate with intragenic or proximal promoter $\mathrm{CpG}$ repeats (within $20 \mathrm{~kb}$ region). The percentage of 50 randomly selected genes is indicated as a proxy for the genome (black bars). Fisher's exact test, ${ }^{*} P<0.05,{ }^{* *} P<0.01,{ }^{* * *} P<0.001$. (B) Validation of differential gene expression in male $(\mathrm{m})$ and female $(\mathrm{f})$ placentas from non-transferred (black bars) and transferred (white bars) conceptuses at E10.5. Data are presented as fold change compared to controls (normalised to 1 ; mean \pm S.D.). $n=4-7$ placentas/group from 3 to 4 litters. Independent $t$ test. ${ }^{\S} P=0.05 ;{ }^{*} P<0.05 ;{ }^{*} P<0.01 ;{ }^{* * *} P<0.001$. (C) Schematic drawings of the Prl3d1 promoter and Rasgrf1 differentially methylated region (DMR). Modified from (Yoon et al. 2005, Hayakawa et al. 2012). Open and closed circles represent unmethylated and methylated CpG sites in placental tissue, respectively. a-d represent regions assessed by bisulfite pyrosequencing in Pr/3d1 promoter. (D and E) CpG site-specific methylation (mean \pm S.E.) in (D) the promoter region of the Prl3d1 gene and (E) the Rasgrf1 DMR as determined via bisulfite pyrosequencing of DNA from control (black squares) and transferred (white squares) female placentas at E10.5. $n=5$ placentas/group from 3 to 4 litters. Independent $t$ tests when primers spanned a single CpG site (i.e. Prl3d1, regions a, b, d) and two-way ANOVA with Sidak's multiple comparisons test when primers spanned two or more CpG sites (i.e. Prl3d1, region c; Rasgrf1 DMR). ${ }^{* * *} P<0.001$.

immunoprecipitation followed by DNA sequencing (ChIP-seq) will be required to explore whether blastocyst transfer affects histone modifications in the placenta.

\section{Discussion}

Evidence suggests that ART might influence pregnancy outcome in an adverse manner; yet, the mechanism is not well understood. Here we showed that blastocyst transfer after natural mating of healthy mice is sufficient to restrict placental growth at midgestation even though the associated embryos were of normal size, or even larger, on average. This phenotype corresponds with a placental transcriptome that was enriched for genes implicated in labyrinth formation, growth, vascular development, and transport function, and implies compensation by the placenta to increase its functional efficiency. Therefore, even minimal embryo manipulation by a technique used in all ART procedures has developmental implications for the placentation site and embryo. Our data suggest that changes in DNA methylation at proximal promoter regions might not disrupt gene expression in the placenta after blastocyst transfer. This is because DEGs were less likely to associate with $\mathrm{CpG}$ islands within a $20 \mathrm{~kb}$ region than genes in the genome at large and DNA methylation patterns remained unchanged in at least two DEG loci compared to non-transfer controls. The genomic clustering of some DEGs warrants further investigation of the effects of blastocyst transfer on longrange, cis-acting epigenetic mechanisms, including histone modifications and DNA methylation. 
Table 5 Differentially expressed genes in placentas from transferred mouse conceptuses at E10.5 with known regulation by DNA methylation.

\begin{tabular}{|c|c|c|c|c|c|}
\hline Gene name & Function & $\begin{array}{l}\text { Known characteristics of epigenetically } \\
\text { regulated expression }\end{array}$ & FC & $\begin{array}{l}\text { Predicted CpG } \\
\text { methylation* }\end{array}$ & Ref. \\
\hline \multicolumn{6}{|c|}{ Downregulated genes } \\
\hline Trpm2 & Cation channel & $\begin{array}{l}\text { Methylation of inner CpG island: } \\
\text { gene repression }\end{array}$ & -10.1 & Hyper & $\begin{array}{l}\text { Orfanelli et al. } \\
2008\end{array}$ \\
\hline Klra4 & $\begin{array}{l}\text { Killer cell lectin-like } \\
\text { receptor; cell adhesion }\end{array}$ & Promoter hypomethylation: gene activation & -8.8 & Hyper & $\begin{array}{l}\text { Rouhi et al. } \\
2009\end{array}$ \\
\hline Dazl & RNA-binding protein & Promoter methylation: gene repression & -5.0 & Hyper & $\begin{array}{l}\text { Hackett et al. } \\
2012\end{array}$ \\
\hline Prl8a1 & Prolactin hormone family & $\begin{array}{l}\text { Placenta-specific promoter hypomethylation: } \\
\text { gene activation }\end{array}$ & -2.9 & Hyper & $\begin{array}{l}\text { Hayakawa et al. } \\
2012\end{array}$ \\
\hline Prl7a1 & Prolactin hormone family & $\begin{array}{l}\text { Placenta-specific promoter hypomethylation: } \\
\text { gene activation }\end{array}$ & -2.9 & Hyper & $\begin{array}{l}\text { Hayakawa et al. } \\
2012\end{array}$ \\
\hline Rasgrf1 & $\begin{array}{l}\text { Guanine nucleotide- } \\
\text { releasing factor }\end{array}$ & $\begin{array}{l}\text { (Imprinted) Paternally inherited allele is } \\
\text { methylated and biallelically expressed in the } \\
\text { placenta; methylation leads to gene activation }\end{array}$ & -2.7 & Нуро & $\begin{array}{l}\text { Yoon et al. } \\
2005 \text {, Dockery } \\
\text { et al. } 2009\end{array}$ \\
\hline Kazald1 & $\begin{array}{l}\text { Insulin growth factor- } \\
\text { binding protein family }\end{array}$ & Promoter hypomethylation: gene activation & -2.3 & Hyper & $\begin{array}{l}\text { Wang et al. } \\
2013 a\end{array}$ \\
\hline $\operatorname{Pr} / 3 d 1$ & Prolactin hormone family & $\begin{array}{l}\text { Placenta-specific promoter hypomethylation: } \\
\text { gene activation }\end{array}$ & -2.0 & Hyper & $\begin{array}{l}\text { Hayakawa et al. } \\
2012\end{array}$ \\
\hline \multicolumn{6}{|c|}{ Upregulated DEGs } \\
\hline Edn2 & Angiogenesis & $\begin{array}{l}\text { Hypomethylation of intragenic region: gene } \\
\text { activation }\end{array}$ & 7.2 & Нуро & $\begin{array}{l}\text { Wang et al. } \\
2013 b\end{array}$ \\
\hline Cldn 11 & Gap junction protein & Promoter hypermethylation: gene repression & 5.9 & Нуро & $\begin{array}{l}\text { Agarwal et al. } \\
2009\end{array}$ \\
\hline Eno2 & Glycolysis & Promoter hypermethylation: gene repression & 5.7 & Нyро & $\begin{array}{l}\text { Wang et al. } \\
2014\end{array}$ \\
\hline Inhba & TGF $\beta$ signalling pathway & $\begin{array}{l}\text { Promoter hypermethylation in human } \\
\text { placenta: gene repression }\end{array}$ & 4.4 & Нуро & $\begin{array}{l}\text { Wilson et al. } \\
2015\end{array}$ \\
\hline$C f b$ & Complement factor & $\begin{array}{l}\text { Promoter hypermethylation: gene repression; } \\
\text { in human placenta, promoter hypomethylated } \\
\text { upon CytoT to SynT differentiation }\end{array}$ & 4.4 & Нyро & Yuen et al. 2013 \\
\hline Tfpi2 & Serine protease & $\begin{array}{l}\text { (Imprinted) Paternally inherited allele is } \\
\text { methylated at the ICR, maternally inherited } \\
\text { allele expressed the placenta }\end{array}$ & 3.1 & Нуро & $\begin{array}{l}\text { Monk et al. } \\
2008\end{array}$ \\
\hline Cobl & Actin interacting protein & $\begin{array}{l}\text { (Imprinted) Tissue-specific parentally biased } \\
\text { expression; methylation on maternally inherited } \\
\text { allele at Grb10 DMR in yolk sac results in Cobl } \\
\text { expression from the maternal allele }\end{array}$ & 2.6 & Hyper & $\begin{array}{l}\text { Shiura et al. } \\
2009\end{array}$ \\
\hline
\end{tabular}

*Predicted change in CpG methylation based on differential expression observed in RNA-sequencing experiment and published data. CytoT, cytotrophoblast; FC, fold change; hyper, hypermethylated; hypo, hypomethylated; ICR, imprinting control region; SynT, syncytiotrophoblast.

Foetal growth is contingent upon a functioning placenta since it is the interface between the maternal and foetal circulations, facilitating gas and metabolic exchange, and hormone production (Watson \& Cross 2005). After blastocyst transfer, we observed placentas that were small at E10.5 suggesting delayed development and/or reduced placental growth. Since the associated embryos were of normal developmental stage and size, the placentas may have adjusted their functional performance to protect the embryo growth trajectory. To achieve this, the placenta might respond to foetal requirements by altering its structure, endocrine function, and/or nutrient transport capacity through transcriptional changes.

In the mouse, the labyrinth layer is the exchange barrier composed of a complex network of trophoblastic villi that separate the foetal capillaries from the maternal blood circulation (Watson \& Cross 2005). We observed several genes associated with labyrinth formation that were upregulated after blastocyst transfer including those involved in branching morphogenesis and vascularisation as determined by genetic knockout mice (Sun et al. 1998, Xue et al. 1998, Liu \& LeRoith 1999, Stumpo et al. 2004, Bell et al. 2006, Smith et al. 2006, Fotopoulou et al. 2010, Goyal et al. 2010, PerezGarcia et al. 2018). These transcriptional changes might promote branching of additional villi and/or increased vascular density of existing villi (Wu et al. 2003) to improve the surface area for exchange. In support of this hypothesis, increased placental vascular density is apparent after IVF (together with embryo transfer) in bovine and ovine conceptuses (Miles et al. 2005, Grazul-Bilska et al. 2014). IVF followed by blastocyst transfer in mice might lead to increased branching morphogenesis since an initially small placenta at E12.5 develops into a large placenta by late gestation (Delle Piane et al. 2010, Bloise et al. 2012). To fully understand the effects of blastocyst transfer alone on mouse 

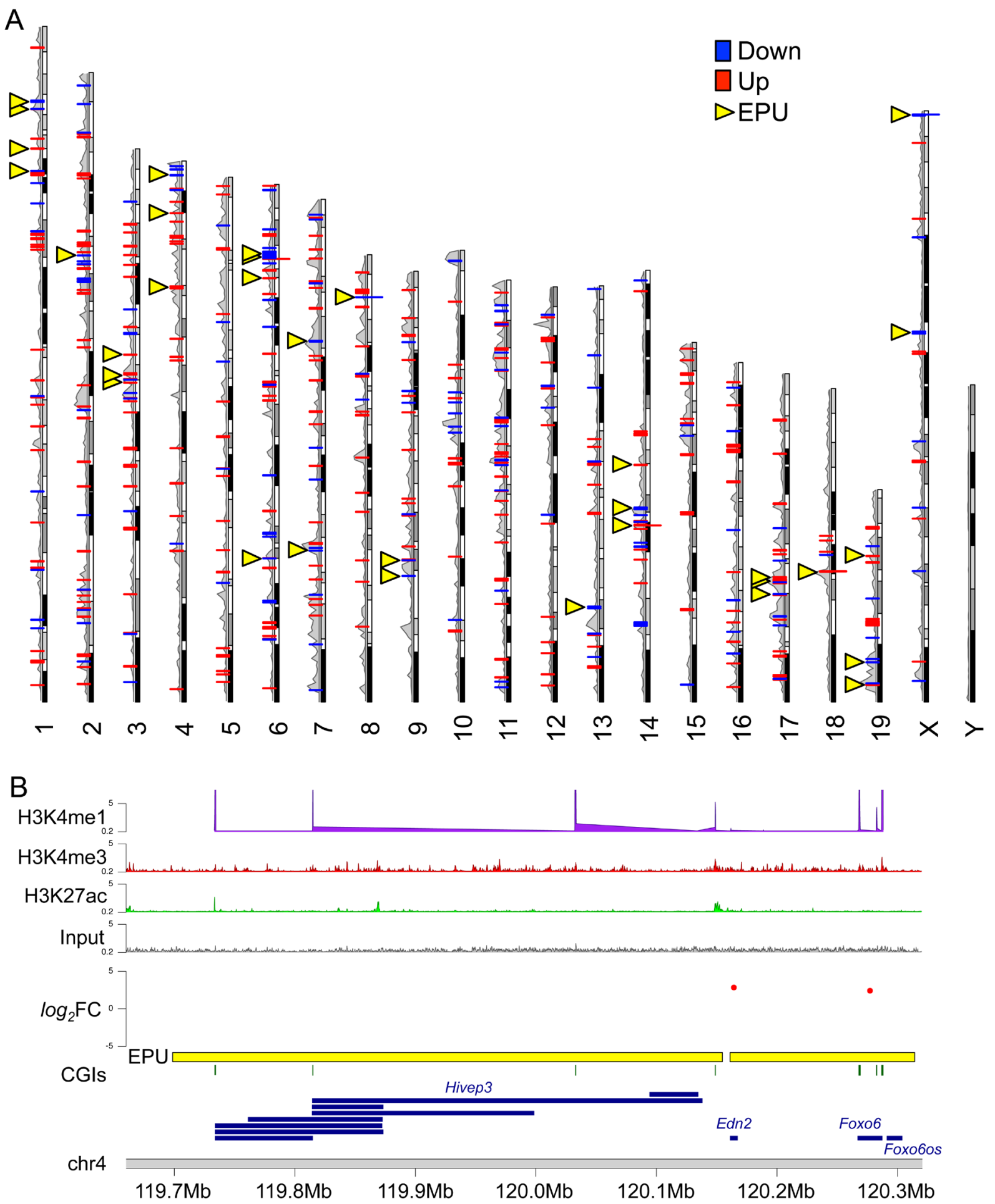

Figure 5 Clustering of differentially expressed genes (DEGs) in the mouse genome suggests shared long-range, cis-acting regulatory regions. (A) Schematic karyoplot representing mouse chromosomes $1-19, X$ and $Y$ indicating the location of DEGs $\left(\log _{2}(\right.$ fold change) $>1)$ in whole placentas after embryo transfer as determined via RNA sequencing. Red, upregulated genes; blue, downregulated genes. Peaks on the left-hand side of each chromosome represent the degree of gene density in that genomic region. Yellow arrowheads indicate enhancer-promoter units (EPUs) containing at least two DEGs. (B, C and D) A schematic representation of two neighbouring EPUs (yellow bars) on chromosome 4 including one EPU (right) that contains the DEGs Edn2 and Foxo6. The level of misexpression of these genes is indicated by the respective red dots on a $\log _{2}$ (fold change) scale. Additional features include chromosomal location of peaks of enrichment for placental histone modifications, such as H3K4me1 (purple peaks), H3K4me3 (red peaks), and H3K27ac (light green peaks) generated using published ChIP-seq data (Yue et al. 2014), CpG islands (CGls; green lines) and genes (blue). Grey peaks indicate ChIP-seq input. See also Supplementary Table 4. 
placental villus structure, a detailed morphological analysis is required. Additionally, it will be interesting to explore how specific transcriptional profiles relate to the morphological differences.

Alternatively, placentas are capable of stimulating nutrient transport to compensate for poor placental growth (Constancia et al. 2002). Similar to studies of whole mouse placentas at E15.5 after IVF without superovulation (Bloise et al. 2012), we observed many upregulated genes in transferred placentas that encode for transport proteins (e.g., Gjb1, gap junction protein; S/c7a9, L-cystine transport; S/c27a2, fatty acid transport; Slc7a11, cysteine/glutamine transport; Apom, lipid transport, etc.) when compared to non-transferred controls. This implies functional compensation by a small placenta in response to foetal requirements. Placental transport assays (Constancia et al. 2002) will be required to more fully understand the degree to which transcriptional upregulation leads to a functional increase in nutrient transport across the placenta. Furthermore, whether the transferred placenta is able to continue to compensate in later stages of gestation as the demands by the fetus increase remains to be determined.

It is possible that blastocyst transfer affects other placental regions (e.g., junctional zone or decidua). For instance, we identified four placenta prolactin cluster genes (Prl2c2, Prl3d1, Prl7a1, Prl8a1), which are solely expressed in the spongiotrophoblast cells and TGC subtypes of the mouse placenta (Simmons et al. 2008) and were downregulated in transferred placentas. Normally, the promoter of the Prl3d1 gene (also known as P/1) is hypomethylated in the mouse placenta compared to adult organs (Hayakawa et al. 2012). While DNA methylation was normal in the Pr/3d1 promoter of transferred placentas, it is possible that changes in histone modifications together with DNA methylation in a more broadly defined region surrounding the $\operatorname{Pr} / 3 d 1$ gene might be implicated. Further analysis of chromatin marks in this genomic region is required. Alternatively, reduced differentiation of progenitor cells within the ectoplacental cone of transferred conceptuses might lead to fewer parietal-TGCs (Pr/3d $1^{+}$cells) and/or spongtiotrophoblast cells $\left(\mathrm{Pr} / 2 \mathrm{C}^{+}, \mathrm{Prl} 7 \mathrm{a} 1^{+}\right.$, or Prl8a $1^{+}$ cells) at E10.5 and thus reduced expression of these genes would result. In support of this hypothesis, Aldh3a1 and I/33, genes that regulate the differentiation and function of the progenitor cells within the ectoplacental cone (Nishiyama et al. 2015, Wang et al. 2017), were also downregulated in transferred placentas. To better understand the effects of blastocyst transfer on trophoblast differentiation, a histological examination and systematic assessment of trophoblast marker gene expression is required. Regardless, altered expression of prolactin cluster genes might have implications for placenta morphology, metabolism, and hormone production (Simmons et al. 2008, Woods et al. 2018).
Many researchers studying the epigenetic effects of ART have performed directed analyses of imprinted regions in placentation sites from mid-to-late gestation (reviewed by Choux et al. 2015) as a read-out of functional changes in genome-wide DNA methylation. Here, we performed a genome-wide approach to assess the placental transcriptome and identified only three misexpressed genes associated with distinct imprinted control regions (i.e., Rasgrf1, Cobl, Tfpi2) (Yoon et al. 2005, Monk et al. 2008, Shiura et al. 2009). Therefore, unlike more invasive ART procedures, blastocyst transfer might not alter DNA methylation to a great extent in the whole placenta at E10.5. Beyond imprinted genes and in support of this hypothesis, fewer misexpressed genes in transferred placentas were associated with intragenic and proximal promoter $\mathrm{CpG}$ islands than the rest of the genome implicating long-range cis-acting epigenetic mechanisms. Furthermore, we showed that at least two DEGs with known regulation by $\mathrm{CpG}$ methylation in the placenta (i.e., Prl3d1 and Rasgrf1) (Yoon et al. 2005, Hayakawa et al. 2012) displayed normal DNA methylation patterns. A whole methylome analysis (e.g., whole genome bisulfite sequencing) will better address whether blastocyst transfer alters DNA methylation in transferred placentas to cause the widespread transcriptional changes.

Our data suggest that blastocyst transfer might disrupt other epigenetic mechanisms, such as histone modifications. The effects of ART on histone modifications are little studied and not well understood. Increased histone acetylation (e.g., H3K9ac, H3K14ac) in mouse zygotes is associated with superovulation (Huffman et al. 2015). Whether these changes are maintained by placenta cell lineages and influence gene expression is unclear. While we did not assess the effects of blastocyst transfer on histone modifications directly, we showed that some DEGs shared cis-acting regulatory elements in the placenta, the identification of which was largely based on the enrichment of histone modifications and RNA polymerase binding (Shen et al. 2012). As a result, these clustered DEGs might be sensitive to regional changes in histone modifications at key stages of development. Interestingly, four DEGs in transferred placentas (i.e., AU022751, Myocd, Chd5, Pygo1) are regulators of histone modifications (Cao et al. 2005, Fiedler et al. 2008, Potts et al. 2011, Zhuang et al. 2014, Maier et al. 2015, Kloet et al. 2016). Indeed, the dysregulation of proteins involved in chromatin remodeling has implications for widespread transcriptional dysregulation beyond the EPUs identified. Therefore, our study sets the stage for future analyses including ChIP-seq experiments, which will be required to explore the effects of blastocyst transfer on the regulation of histone modifications.

How blastocyst transfer alters placental gene expression remains unclear. The establishment of epigenetic marks is initiated at the blastocyst stage 
(Hanna et al. 2018). Therefore, it is possible that the stress of a brief culture period, embryo handling, and/or placement into a new uterine environment during this key epigenetic milestone is sufficient to alter epigenetic marks and subsequent gene expression required for cells to differentiate and function. Since all ART require blastocyst transfer, it will be important to tease apart the transcriptional and developmental effects of the transfer process from the more invasive techniques. Furthermore, the ART field will benefit from epigenome-wide analyses of placentas derived from these technologies including DNA methylation together with histone modifications with the aim of looking beyond imprinted loci. This will allow for a holistic picture of the epigenetic framework that gives rise to transcriptional and functional changes in the placenta after ART, and thus, the immediate and long-term effects on the fetus.

\section{Supplementary materials}

This is linked to the online version of the paper at https://doi.org/10.1530/REP-19-0293.

\section{Declaration of interest}

E D W is an Associate Editor of Reproduction. E D W was not involved in the review or editorial process for this paper, on which she is listed as an author. The other authors have nothing to disclose.

\section{Funding}

This work was supported by grants from the Centre for Trophoblast Research (CTR) (to E D W), Lister Institute for Preventative Medicine (to E D W), and Canadian Institutes for Health Research (to J C C). K M was funded by a Newnham College (Cambridge) studentship and A.G. Leventis scholarship. S J T was funded by a Next Generation Fellowship (CTR). G E T B was funded by a Wellcome Trust PhD studentship in Developmental Mechanisms. R S H and M P were funded by the CTR.

\section{Author contribution statement}

E D W conceived the study. K M, R S H and E D W designed the experiments. $\mathrm{R} \mathrm{S} \mathrm{H}$ and $M \mathrm{P}$ performed the bioinformatic analysis. C G J, K M, M P, S J T, G E T B, and E D W performed experiments, analysed the data, and interpreted the results. $E$ D W and J C C obtained funding. E D W and K M wrote the manuscript. All authors read and edited the manuscript.

\section{Acknowledgements}

RNA library preparation and sequencing was performed by Cambridge Genomic Services (Department of Pathology, University of Cambridge).

\section{References}

Agarwal R, Mori Y, Cheng Y, Jin Z, Olaru AV, Hamilton JP, David S, Selaru FM, Yang J, Abraham JM et al. 2009 Silencing of claudin-11 is associated with increased invasiveness of gastric cancer cells. PLOS ONE 4 e8002. (https://doi.org/10.1371/journal.pone.0008002)

Bell SE, Sanchez MJ, Spasic-Boskovic O, Santalucia T, Gambardella L, Burton GJ, Murphy IJ, Norton JD, Clark AR \& Turner M 2006 The RNA binding protein Zfp36l1 is required for normal vascularisation and posttranscriptionally regulates VEGF expression. Developmental Dynamics 235 3144-3155. (https://doi.org/10.1002/dvdy.20949)

Bloise E, Lin W, Liu X, Simbulan R, Kolahi KS, Petraglia F, Maltepe E, Donjacour A \& Rinaudo P 2012 Impaired placental nutrient transport in mice generated by in vitro fertilization. Endocrinology 153 3457-3467. (https://doi.org/10.1210/en.2011-1921)

Canovas S, Ross PJ, Kelsey G \& Coy P 2017 DNA methylation in embryo development: epigenetic impact of ART (assisted reproductive technologies). BioEssays 39. (https://doi.org/10.1002/bies.201700106)

Cao D, Wang Z, Zhang CL, Oh J, Xing W, Li S, Richardson JA, Wang DZ \& Olson EN 2005 Modulation of smooth muscle gene expression by association of histone acetyltransferases and deacetylases with myocardin. Molecular and Cellular Biology 25 364-376. (https://doi. org/10.1128/MCB.25.1.364-376.2005)

Chen EY, Tan CM, Kou Y, Duan Q, Wang Z, Meirelles GV, Clark NR \& Ma'ayan A 2013 Enrichr: interactive and collaborative HTML5 gene list enrichment analysis tool. BMC Bioinformatics 14 128. (https://doi. org/10.1186/1471-2105-14-128)

Chen S, Sun F-Z, Huang X, Wang X, Tang N, Zhu B \& Li B 2015 Assisted reproduction causes placental maldevelopment and dysfunction linked to reduced fetal weight in mice. Scientific Reports 510596 (https://doi. org/10.1038/srep10596)

Choux C, Carmignac V, Bruno C, Sagot P, Vaiman D \& Fauque P 2015 The placenta: phenotypic and epigenetic modifications induced by Assisted Reproductive Technologies throughout pregnancy. Clinical Epigenetics 7 87. (https://doi.org/10.1186/s13148-015-0120-2)

Chuma S \& Nakatsuji N 2001 Autonomous transition into meiosis of mouse fetal germ cells in vitro and its inhibition by gp130-mediated signaling. Developmental Biology 229 468-479. (https://doi.org/10.1006/ dbio.2000.9989)

Constancia $M$, Hemberger $M$, Hughes J, Dean W, Ferguson-Smith A, Fundele R, Stewart F, Kelsey G, Fowden A, Sibley C et al. 2002 Placentalspecific IGF-II is a major modulator of placental and fetal growth. Nature 417 945-948. (https://doi.org/10.1038/nature00819)

de Waal E, Mak W, Calhoun S, Stein P, Ord T, Krapp C, Coutifaris C, Schultz RM \& Bartolomei MS 2014 In vitro culture increases the frequency of stochastic epigenetic errors at imprinted genes in placenta tissues from mouse concepti produced through assisted reproductive technologies. Biology of Reproduction 90 22. (https://doi.org/10.1095/ biolreprod.113.114785)

Delle Piane L, Lin W, Liu X, Donjacour A, Minasi P, Revelli A, Maltepe E \& Rinaudo PF 2010 Effect of the method of conception and embryo transfer procedure on mid-gestation placenta and fetal development in an IVF mouse model. Human Reproduction 25 2039-2046. (https://doi. org/10.1093/humrep/deq165)

Dockery L, Gerfen J, Harview C, Rahn-Lee C, Horton R, Park Y \& Davis TL 2009 Differential methylation persists at the mouse Rasgrf1 DMR in tissues displaying monoallelic and biallelic expression. Epigenetics $\mathbf{4}$ 241-247. (https://doi.org/10.4161/epi.9021)

ENCODE Project Consortium Encode 2012. An integrated encyclopedia of DNA elements in the human genome. Nature $\mathbf{4 8 9} 57-74$. (https://doi. org/10.1038/nature11247)

European Society of Human Reproduction and Embryology (ESHRE) 2018 ART fact sheet. Grimbergen, Belgium. (available at: https://www.eshre.eu/)

Fauque P, Ripoche MA, Tost J, Journot L, Gabory A, Busato F, Le Digarcher A, Mondon F, Gut I, Jouannet P et al. 2010 Modulation of imprinted gene network in placenta results in normal development of in vitro manipulated mouse embryos. Human Molecular Genetics 19 1779-1790. (https://doi.org/10.1093/hmg/ddq059)

Fiedler M, Sanchez-Barrena MJ, Nekrasov M, Mieszczanek J, Rybin V, Muller J, Evans P \& Bienz M 2008 Decoding of methylated histone H3 tail by the Pygo-BCL9 Wnt signaling complex. Molecular Cell 30 507-518. (https://doi.org/10.1016/j.molcel.2008.03.011) 
Fortier AL, Lopes FL, Darricarrere N, Martel J \& Trasler JM 2008 Superovulation alters the expression of imprinted genes in the midgestation mouse placenta. Human Molecular Genetics 17 1653-1665. (https://doi.org/10.1093/hmg/ddn055)

Fotopoulou S, Oikonomou N, Grigorieva E, Nikitopoulou I, Paparountas T, Thanassopoulou A, Zhao Z, Xu Y, Kontoyiannis DL, Remboutsika E et al. 2010 ATX expression and LPA signalling are vital for the development of the nervous system. Developmental Biology 339 451-464. (https://doi. org/10.1016/j.ydbio.2010.01.007)

Gardiner-Garden M \& Frommer M 1987 CpG islands in vertebrate genomes. Journal of Molecular Biology 196 261-282. (http://doi. org/10.1016/0022-2836(87)90689-9)

Gonzalez TL, Sun T, Koeppel AF, Lee B, Wang ET, Farber CR, Rich SS, Sundheimer LW, Buttle RA, Chen YI et al. 2018 Sex differences in the late first trimester human placenta transcriptome. Biology of Sex Differences 9 4. (https://doi.org/10.1186/s13293-018-0165-y)

Goyal R, Yellon SM, Longo LD \& Mata-Greenwood E 2010 Placental gene expression in a rat 'model' of placental insufficiency. Placenta 31 568-575. (https://doi.org/10.1016/j.placenta.2010.05.004)

Grazul-Bilska AT, Johnson ML, Borowicz PP, Bilski JJ, Cymbaluk T, Norberg S, Redmer DA \& Reynolds LP 2014 Placental development during early pregnancy in sheep: effects of embryo origin on vascularization. Reproduction 147 639-648. (https://doi.org/10.1530/ REP-13-0663)

Guller S, Buhimschi CS, Ma YY, Huang ST, Yang L, Kuczynski E, Zambrano E, Lockwood CJ \& Buhimschi IA 2008 Placental expression of ceruloplasmin in pregnancies complicated by severe preeclampsia. Laboratory Investigation 88 1057-1067. (https://doi.org/10.1038/ labinvest.2008.74)

Guo XY, Liu XM, Jin L, Wang TT, Ullah K, Sheng JZ \& Huang HF 2017 Cardiovascular and metabolic profiles of offspring conceived by assisted reproductive technologies: a systematic review and meta-analysis. Fertility and Sterility 107 622.e5-631.e5. (https://doi.org/10.1016/j. fertnstert.2016.12.007)

Haavaldsen C, Tanbo T \& Eskild A 2012 Placental weight in singleton pregnancies with and without assisted reproductive technology: a population study of 536,567 pregnancies. Human Reproduction 27 576-582. (https://doi.org/10.1093/humrep/der428)

Hackett JA, Reddington JP, Nestor CE, Dunican DS, Branco MR, Reichmann J, Reik W, Surani MA, Adams IR \& Meehan RR 2012 Promoter DNA methylation couples genome-defence mechanisms to epigenetic reprogramming in the mouse germline. Development 139 3623-3632. (https://doi.org/10.1242/dev.081661)

Haeussler M, Zweig AS, Tyner C, Speir ML, Rosenbloom KR, Raney BJ, Lee CM, Lee BT, Hinrichs AS, Gonzalez JN et al. 2019 The UCSC Genome Browser database: 2019 update. Nucleic Acids Research 47 D853-D858. (https://doi.org/10.1093/nar/gky1095)

Han X, Wang R, Zhou Y, Fei L, Sun H, Lai S, Saadatpour A, Zhou Z, Chen H, Ye F et al. 2018 Mapping the mouse cell atlas by microwell-Seq. Cell 172 1091.e17-1107.e17. (https://doi.org/10.1016/j.cell.2018.02.001)

Hanna CW, Demond H \& Kelsey G 2018 Epigenetic regulation in development: is the mouse a good model for the human? Human Reproduction Update 24 556-576. (https://doi.org/10.1093/humupd/ dmy021)

Hayakawa K, Nakanishi MO, Ohgane J, Tanaka S, Hirosawa M, Soares MJ, Yagi S \& Shiota K 2012 Bridging sequence diversity and tissue-specific expression by DNA methylation in genes of the mouse prolactin superfamily. Mammalian Genome 23 336-345. (https://doi.org/10.1007/ s00335-011-9383-x)

Huffman SR, Pak Y \& Rivera RM 2015 Superovulation induces alterations in the epigenome of zygotes, and results in differences in gene expression at the blastocyst stage in mice. Molecular Reproduction and Development 82 207-217. (https://doi.org/10.1002/mrd.22463)

Ishikawa H, Seki R, Yokonishi S, Yamauchi T \& Yokoyama K 2006 Relationship between fetal weight, placenta growth and litter size in mice from. Reproductive Toxicology 21 267-270. (https://doi.org/10.1016/j. reprotox.2005.08.002)

Khosla S, Dean W, Brown D, Reik W \& Feil R 2001 Culture of preimplantation mouse embryos affects fetal development and the expression of imprinted genes. Biology of Reproduction 64 918-926. (https://doi.org/10.1095/biolreprod64.3.918)

Kloet SL, Makowski MM, Baymaz HI, van Voorthuijsen L, Karemaker ID, Santanach A, Jansen PWTC, Di Croce L \& Vermeulen M 2016 The dynamic interactome and genomic targets of Polycomb complexes during stem-cell differentiation. Nature Structural and Molecular Biology 23 682-690. (https://doi.org/10.1038/nsmb.3248)

Kuleshov MV, Jones MR, Rouillard AD, Fernandez NF, Duan Q, Wang Z, Koplev S, Jenkins SL, Jagodnik KM, Lachmann A et al. 2016 Enrichr: a comprehensive gene set enrichment analysis web server 2016 update. Nucleic Acids Research 44 W90-W97. (https://doi.org/10.1093/nar/ gkw377)

Lee J, Oh JS \& Cho C 2011 Impaired expansion of trophoblast spheroids cocultured with endometrial cells overexpressing cellular retinoic acidbinding protein 2. Fertility and Sterility 95 2599-2601. (https://doi. org/10.1016/j.fertnstert.2011.04.065)

Liu JL \& LeRoith D 1999 Insulin-like growth factor I is essential for postnatal growth in response to growth hormone. Endocrinology 140 5178-5184. (https://doi.org/10.1210/endo.140.11.7151)

Liu H, Zhang Y, Gu HT, Feng QL, Liu JY, Zhou J \& Yan F 2015 Association between assisted reproductive technology and cardiac alteration at age 5 years. JAMA Pediatrics 169 603-605. (https://doi.org/10.1001/ jamapediatrics.2015.0214)

Maier VK, Feeney CM, Taylor JE, Creech AL, Qiao JW, Szanto A, Das PP, Chevrier N, Cifuentes-Rojas C, Orkin SH et al. 2015 Functional proteomic analysis of repressive histone methyltransferase complexes reveals ZNF518B as a G9A regulator. Molecular and Cellular Proteomics 14 1435-1446. (https://doi.org/10.1074/mcp.M114.044586)

Mann MR, Lee SS, Doherty AS, Verona RI, Nolen LD, Schultz RM \& Bartolomei MS 2004 Selective loss of imprinting in the placenta following preimplantation development in culture. Development 131 3727-3735. (https://doi.org/10.1242/dev.01241)

Miles JR, Farin CE, Rodriguez KF, Alexander JE \& Farin PW 2005 Effects of embryo culture on angiogenesis and morphometry of bovine placentas during early gestation. Biology of Reproduction 73 663-671. (https://doi. org/10.1095/biolreprod.105.040808)

Monk D, Wagschal A, Arnaud P, Muller PS, Parker-Katiraee L, Bourc'his D, Scherer SW, Feil R, Stanier P \& Moore GE 2008 Comparative analysis of human chromosome $7 q 21$ and mouse proximal chromosome 6 reveals a placental-specific imprinted gene, TFPI2/Tfpi2, which requires EHMT2 and EED for allelic-silencing. Genome Research 18 1270-1281. (https:// doi.org/10.1101/gr.077115.108)

Nishiyama M, Nita A, Yumimoto K \& Nakayama KI 2015 FBXL12-mediated degradation of ALDH3 is essential for trophoblast differentiation during placental development. Stem Cells 33 3327-3340. (https://doi. org/10.1002/stem.2088)

Orfanelli U, Wenke AK, Doglioni C, Russo V, Bosserhoff AK \& Lavorgna G 2008 Identification of novel sense and antisense transcription at the TRPM2 locus in cancer. Cell Research 18 1128-1140. (https://doi. org/10.1038/cr.2008.296)

Ozler S, Oztas E, Guler BG, Pehlivan S, Kadioglu N, Ergin M, Uygur D \& Danisman N 2016 Role of ADAMTS5 in unexplained fetal growth restriction (FGR). Fetal and Pediatric Pathology 35 220-230. (https://doi. org/10.3109/15513815.2016.1173146)

Padmanabhan N, Jia D, Geary-Joo C, Wu X, Ferguson-Smith AC, Fung E, Bieda MC, Snyder FF, Gravel RA, Cross JC et al. 2013 Mutation in folate metabolism causes epigenetic instability and transgenerational effects on development. Cell 155 81-93. (https://doi.org/10.1016/j. cell.2013.09.002)

Perez-Garcia V, Fineberg E, Wilson R, Murray A, Mazzeo Cl, Tudor C, Sienerth A, White JK, Tuck E, Ryder EJ et al. 2018 Placentation defects are highly prevalent in embryonic lethal mouse mutants. Nature $\mathbf{5 5 5}$ 463-468. (https://doi.org/10.1038/nature26002)

Potts RC, Zhang P, Wurster AL, Precht P, Mughal MR, Wood 3rd WH, Zhang Y, Becker KG, Mattson MP \& Pazin MJ 2011 CHD5, a brainspecific paralog of $\mathrm{Mi} 2$ chromatin remodeling enzymes, regulates expression of neuronal genes. PLOS ONE 6 e24515. (https://doi. org/10.1371/journal.pone.0024515)

Quinn M \& Fujimoto V 2016 Racial and ethnic disparities in assisted reproductive technology access and outcomes. Fertility and Sterility $\mathbf{1 0 5}$ 1119-1123. (https://doi.org/10.1016/j.fertnstert.2016.03.007)

Rivera RM, Stein P, Weaver JR, Mager J, Schultz RM \& Bartolomei MS 2008 Manipulations of mouse embryos prior to implantation result in aberrant expression of imprinted genes on day 9.5 of development. Human Molecular Genetics 17 1-14. (https://doi.org/10.1093/hmg/ddm280)

Rouhi A, Lai CB, Cheng TP, Takei F, Yokoyama WM \& Mager DL 2009 Evidence for high bi-allelic expression of activating Ly49 receptors. 
Nucleic Acids Research 37 5331-5342. (https://doi.org/10.1093/nar/ gkp592)

Shen Y, Yue F, McCleary DF, Ye Z, Edsall L, Kuan S, Wagner U, Dixon J, Lee L, Lobanenkov VV et al. 2012 A map of the cis-regulatory sequences in the mouse genome. Nature 488 116-120. (https://doi.org/10.1038/ nature11243)

Shiura H, Nakamura K, Hikichi T, Hino T, Oda K, Suzuki-Migishima R, Kohda T, Kaneko-ishino T \& Ishino F 2009 Paternal deletion of Meg1/ Grb10 DMR causes maternalization of the Meg1/Grb10 cluster in mouse proximal chromosome 11 leading to severe pre- and postnatal growth retardation. Human Molecular Genetics 18 1424-1438. (https://doi. org/10.1093/hmg/ddp049)

Simmons DG, Rawn S, Davies A, Hughes M \& Cross JC 2008 Spatial and temporal expression of the 23 murine prolactin/placental lactogenrelated genes is not associated with their position in the locus. BMC Genomics 9 352. (https://doi.org/10.1186/1471-2164-9-352)

Smith BT, Mussell JC, Fleming PA, Barth JL, Spyropoulos DD, Cooley MA, Drake CJ \& Argraves WS 2006 Targeted disruption of cubilin reveals essential developmental roles in the structure and function of endoderm and in somite formation. BMC Developmental Biology 6 30. (https://doi. org/10.1186/1471-213X-6-30)

Stumpo DJ, Byrd NA, Phillips RS, Ghosh S, Maronpot RR, Castranio T, Meyers EN, Mishina Y \& Blackshear PJ 2004 Chorioallantoic fusion defects and embryonic lethality resulting from disruption of Zfp36L1, a gene encoding a $\mathrm{CCCH}$ tandem zinc finger protein of the tristetraprolin family. Molecular and Cellular Biology 24 6445-6455. (https://doi. org/10.1128/MCB.24.14.6445-6455.2004)

Sun WY, Witte DP, Degen JL, Colbert MC, Burkart MC, Holmback K, Xiao Q, Bugge TH \& Degen SJ 1998 Prothrombin deficiency results in embryonic and neonatal lethality in mice. PNAS 95 7597-7602. (https:// doi.org/10.1073/pnas.95.13.7597)

Tararbit K, Lelong N, Thieulin AC, Houyel L, Bonnet D, Goffinet F, Khoshnood B \& EPICARD Study Group 2013 The risk for four specific congenital heart defects associated with assisted reproductive techniques: a population-based evaluation. Human Reproduction $\mathbf{2 8}$ 367-374. (https://doi.org/10.1093/humrep/des400)

Thomopoulos C, Tsioufis C, Michalopoulou H, Makris T, Papademetriou V \& Stefanadis C 2013 Assisted reproductive technology and pregnancyrelated hypertensive complications: a systematic review. Journal of Human Hypertension 27 148-157. (https://doi.org/10.1038/ jhh.2012.13)

Tunster SJ 2017 Genetic sex determination of mice by simplex PCR. Biology of Sex Differences 8 31. (https://doi.org/10.1186/s13293-0170154-6)

Tunster SJ, Jensen AB \& John RM 2013 Imprinted genes in mouse placental development and the regulation of fetal energy stores. Reproduction 145 R117-R137. (https://doi.org/10.1530/REP-12-0511)

Ueda O, Yorozu K, Kamada N, Jishage K, Kawase Y, Toyoda Y \& Suzuki H 2003 Possible expansion of 'Window of Implantation' in pseudopregnant mice: time of implantation of embryos at different stages of development transferred into the same recipient. Biology of Reproduction 69 1085-1090. (https://doi.org/10.1095/biolreprod.103.017608)

Valenzuela-Alcaraz B, Crispi F, Bijnens B, Cruz-Lemini $M$, Creus $M$, Sitges M, Bartrons J, Civico S, Balasch J \& Gratacos E 2013 Assisted reproductive technologies are associated with cardiovascular remodeling in utero that persists postnatally. Circulation 128 1442-1450. (https:// doi.org/10.1161/CIRCULATIONAHA.113.002428)

Wang Z, Xu L \& He F 2010 Embryo vitrification affects the methylation of the $H 19 / / g f 2$ differentially methylated domain and the expression of $H 19$ and Igf2. Fertility and Sterility 93 2729-2733. (https://doi.org/10.1016/j. fertnstert.2010.03.025)

Wang H, Feng Y, Bao Z, Jiang C, Yan W, Wang Y, Zhang C, Liu Y, Zhang Q, Zhang $\mathbf{W}$ et al. 2013a Epigenetic silencing of KAZALD1 confers a better prognosis and is associated with malignant transformation/progression in glioma. Oncology Reports 30 2089-2096. (https://doi.org/10.3892/ or.2013.2706)
Wang R, Lohr CV, Fischer K, Dashwood WM, Greenwood JA, Ho E, Williams DE, Ashktorab H, Dashwood MR \& Dashwood RH 2013b Epigenetic inactivation of endothelin-2 and endothelin-3 in colon cancer. International Journal of Cancer 132 1004-1012. (https://doi. org/10.1002/ijc.27762)

Wang Y, Fang Y, Zhang F, Xu M, Zhang J, Yan J, Ju W, Brown WT \& Zhong N 2014 Hypermethylation of the enolase gene (ENO2) in autism. European Journal of Pediatrics 173 1233-1244. (https://doi.org/10.1007/ s00431-014-2311-9)

Wang XH, Liu W, Fan DX, Hu WT, Li MQ, Zhu XY \& Jin LP 2017 IL33 restricts invasion and adhesion of trophoblast cell line JEG3 by downregulation of integrin alpha4beta1 and CD62L. Molecular Medicine Reports 16 3887-3893. (https://doi.org/10.3892/mmr.2017.7085)

Watson ED \& Cross JC 2005 Development of structures and transport functions in the mouse placenta. Physiology 20 180-193. (https://doi. org/10.1152/physiol.00001.2005)

Weinerman R, Ord T, Bartolomei MS, Coutifaris C \& Mainigi M 2017 The superovulated environment, independent of embryo vitrification, results in low birthweight in a mouse model. Biology of Reproduction 97 133-142. (https://doi.org/10.1093/biolre/iox067)

Wilson SL, Blair JD, Hogg K, Langlois S, von Dadelszen P \& Robinson WP 2015 Placental DNA methylation at term reflects maternal serum levels of Inha and FN1, but not PAPPA, early in pregnancy. BMC Medical Genetics 16 111. (https://doi.org/10.1186/s12881-015-0257-z)

Woods L, Perez-Garcia V \& Hemberger M 2018 Regulation of placental development and its impact on fetal growth-new insights From mouse models. Frontiers in Endocrinology 9 570. (https://doi.org/10.3389/ fendo.2018.00570)

Wu L, de Bruin A, Saavedra HI, Starovic M, Trimboli A, Yang Y, Opavska J, Wilson P, Thompson JC, Ostrowski MC et al. 2003 Extra-embryonic function of $\mathrm{Rb}$ is essential for embryonic development and viability. Nature 421 942-947. (https://doi.org/10.1038/nature01417)

Xue J, Wu Q, Westfield LA, Tuley EA, Lu D, Zhang Q, Shim K, Zheng X \& Sadler JE 1998 Incomplete embryonic lethality and fatal neonatal hemorrhage caused by prothrombin deficiency in mice. PNAS 95 7603-7607. (https://doi.org/10.1073/pnas.95.13.7603)

Ye J, Coulouris G, Zaretskaya I, Cutcutache I, Rozen S \& Madden TL 2012 Primer-BLAST: a tool to design target-specific primers for polymerase chain reaction. BMC Bioinformatics 13 134. (https://doi. org/10.1186/1471-2105-13-134)

Yoon B, Herman H, Hu B, Park YJ, Lindroth A, Bell A, West AG, Chang Y, Stablewski A, Piel JC et al. 2005 Rasgrf1 imprinting is regulated by a CTCF-dependent methylation-sensitive enhancer blocker. Molecular and Cellular Biology 25 11184-11190. (https://doi.org/10.1128/ MCB.25.24.11184-11190.2005)

Yue F, Cheng Y, Breschi A, Vierstra J, Wu W, Ryba T, Sandstrom R, Ma Z, Davis C, Pope BD et al. 2014 A comparative encyclopedia of DNA elements in the mouse genome. Nature 515 355-364. (https://doi. org/10.1038/nature13992)

Yuen RK, Chen B, Blair JD, Robinson WP \& Nelson DM 2013 Hypoxia alters the epigenetic profile in cultured human placental trophoblasts. Epigenetics 8 192-202. (https://doi.org/10.4161/epi.23400)

Zhuang T, Hess RA, Kolla V, Higashi M, Raabe TD \& Brodeur GM 2014 CHD5 is required for spermiogenesis and chromatin condensation. Mechanisms of Development 131 35-46. (https://doi.org/10.1016/j. mod.2013.10.005)

Received 3 July 2019

First decision 6 August 2019

Revised manuscript received 12 November 2019

Accepted 18 November 2019 